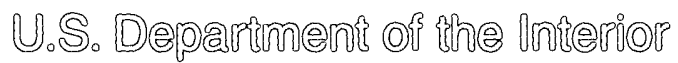 U.S. Gaological Survey
}

Nurrreni and Suspended Solids Loads, Yields, and Trends inn the Non-Tidal Par of Five Major River Basing inn Virgionina, 1985 -96

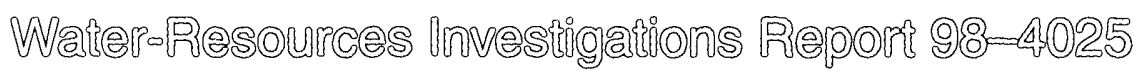

Prepalied in corperanion with

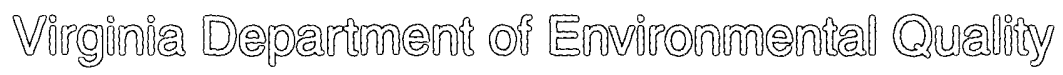
Chesapeake Bay Program

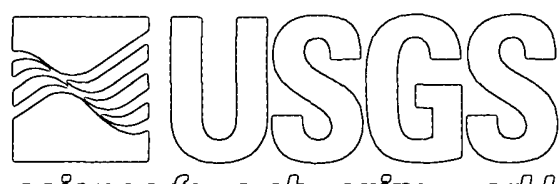




\title{
Nutrient and Suspended Solids Loads, Yields, and Trends in the Non-Tidal Part of Five Major River Basins in Virginia, 1985-96
}

\author{
By Henry M. Johnson, IV and Donna L. Belval
}

U.S. GEOLOGICAL SURVEY

Water-Resources Investigations Report 98-4025

Prepared in cooperation with the

VIRGINIA DEPARTMENT OF ENVIRONMENTAL QUALITY, CHESAPEAKE BAY PROGRAM

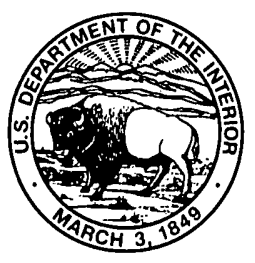




\title{
U.S. DEPARTMENT OF THE INTERIOR BRUCE BABBITT, Secretary
}

\author{
U.S. GEOLOGICAL SURVEY
}

Thomas J. Casadevall, Acting Director

For additional information write to:

District Chief

U.S. Geologica! Survey

3600 West Broad Street, Room 606

Richmond, VA 23230-4916
Copies of this report can be purchased from:

U.S. Geological Survey

Information Services

Box 25286

Denver, CO 80225-0046 


\section{CONTENTS}

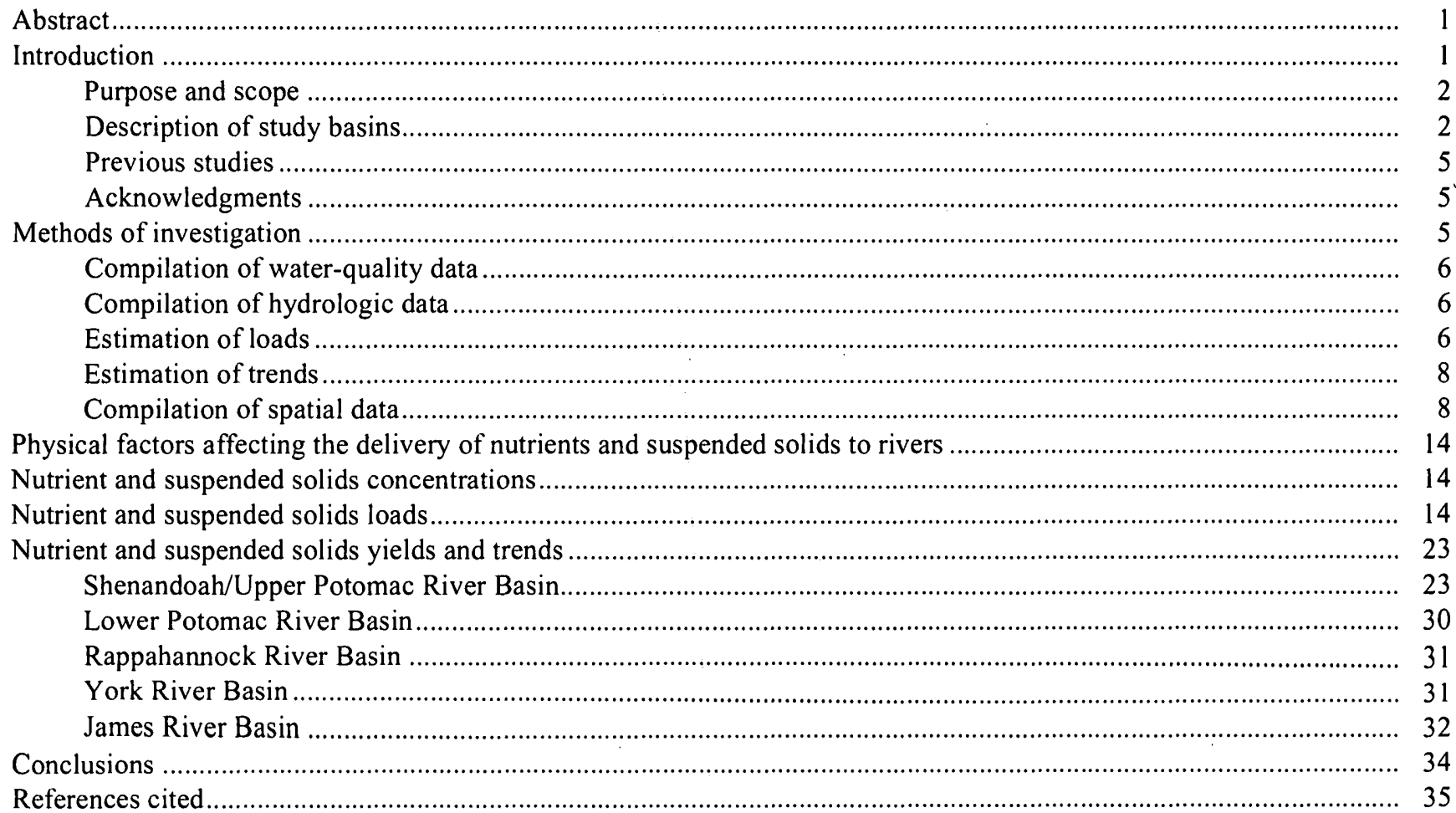

\section{FIGURES}

1. Map showing locations of major river basins, subbasins, and load stations.

2, 3. Bar graphs showing difference in the calculated annual loads of:

2. Total suspended solids for the James River at Cartersville and Richmond, 1985-96.................................

3. Total nitrogen for the James River at Cartersville and Richmond, 1985-96 ........................................ 8

4, 5. Maps showing:

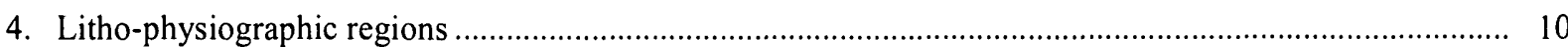

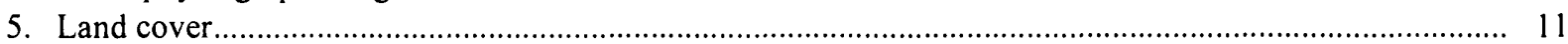

6-10. Box plots showing distribution of concentrations of selected constituents at stations in the:

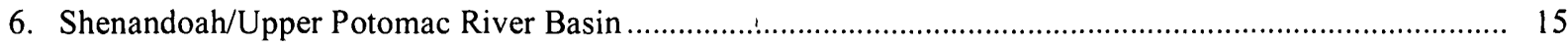

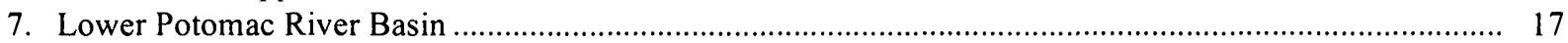

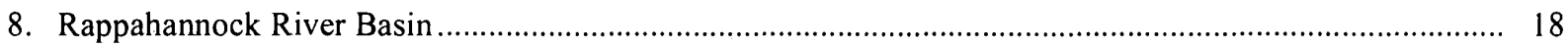

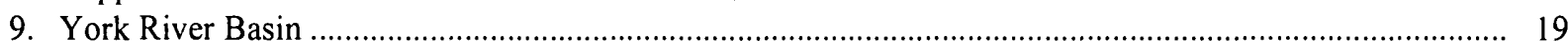

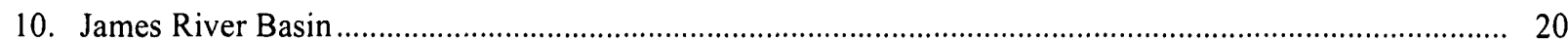

11-12. Graphs showing relation between mean annual yield of total nitrogen, total phosphorus, and total suspended solids in the Shenandoah/Upper Potomac River Basin and:

11. Percent agricultural land cover

12. Percent Valley and Ridge carbonate litho-physiographic region......

13. Graph showing relation between percent Valley and Ridge carbonate litho-physiographic region and percent agricultural land cover in the Shenandoah/Upper Potomac River Basin

14. Bar graph showing annual yield of total nitrogen and total Kjeldahl nitrogen in the Jackson River Basin, $1985-96$ 


\section{TABLES}

1. Location of load stations

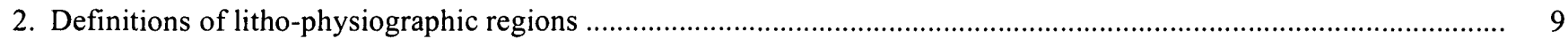

3. Consolidation of U.S. Environmental Protection Agency land cover classes ........................................................... 9

4. Distribution of land cover and litho-physiographic region in each subbasin ........................................................... 12

5. Mean annual load of total nitrogen, total phosphorus, and total suspended solids at each load station

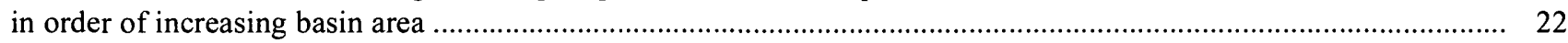

6. Mean annual yield and period of record for selected constituents ........................................................................ 24

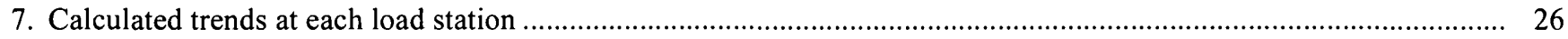

8. Ranges of mean annual yields of major nutrients and total suspended solids in the Shenandoah/Upper

Potomac River Basin

\section{CONVERSION FACTORS AND ABBREVIATED WATER-QUALITY UNITS}

\begin{tabular}{|c|c|c|}
\hline Multiply & By & To obtain \\
\hline acre & 4,047 & square meter \\
\hline acre & 0.4047 & hectare \\
\hline mile (mi) & 1.609 & kilometer \\
\hline square mile $\left(\mathrm{mi}^{2}\right)$ & 259.0 & hectare \\
\hline square mile $\left(\mathrm{mi}^{2}\right)$ & 2.590 & square kilometer \\
\hline pound, avoirdupois (lb) & 0.4536 & kilogram \\
\hline ton, short & 0.9072 & megagram \\
\hline cubic foot per second $\left(\mathrm{ft}^{3} / \mathrm{s}\right)$ & 0.02832 & cubic meter per second \\
\hline pounds per acre per year $[(\mathrm{lb} / \mathrm{acre}) / \mathrm{yr}]$ & 1.121 & kilograms per hectare per year \\
\hline
\end{tabular}

\footnotetext{
Abbreviated water-quality units: Chemical concentration is reported in milligrams per liter (mg/L). Milligrams per liter is a unit expressing the concentration of chemical constituents in solution as weight (milligrams) of solute per unit volume (liter) of water. One thousand micrograms per liter is equivalent to one milligram per liter. For concentrations less than 7,000 mg/L, the numerical value is the same as for concentrations in parts per million.
} 


\title{
Nutrient and Suspended Solids Loads, Yields, and Trends in the Non-Tidal Part of Five Major River Basins in Virginia, 1985-96
}

\author{
By Henry M. Johnson, IV and Donna L. Belval
}

\section{Abstract}

Water quality in Chesapeake Bay has been adversely affected by agricultural, industrial, and urban development in the watershed. To assess the effects of these activities on water quality in the non-tidal part of the Bay's watershed in Virginia, nutrient and suspended solids concentration data, collected by Federal and State agencies between 1985 and 1996, were compiled and analyzed. The annual load, yield, and trends in nutrient and suspended solids concentrations for 35 stations were computed. The anriual yields were analyzed spatially by comparing geology and land cover within and between five major river basins in Virginia: Shenandoah/Upper Potomac, Lower Potomac, Rappahannock, York, and James.

Three water-quality constituents - total nitrogen, total phosphorus, and total suspended solids - were the focus of the spatial analyses. The range in the mean annual load of total nitrogen was 21 to 6,770 tons/year, the range in the mean annual load of total phosphorus was 5 to 1,518 tons/year, and the range in the mean annual load of total suspended solids was 159 to 812,894 tons/year. In general, the load increased with basin area. Mean annual yields of total nitrogen ranged from 1.38 to 15.05 (pounds/acre)/year. The lowest values of loads and yields generally were those for basins having high percentages of forested land cover and siliciclastic rock. The highest values of total nitrogen usually were associated with basins having large percentages of agriculture, urban areas, or carbonate rock. The mean annual yield of total nitrogen was highest in the Shenandoah/Upper Potomac River Basin. The mean annual yield of total phosphorus ranged from 0.17 to 3.15 (pounds/acre)/year. The largest mean annual yield of total phosphorus was found in the upper James River Basin and was attributed to incomplete wastewater treatment during the early years of the study period. Values of mean annual yield of total phosphorus among the highest values determined for the entire study area were found in subbasins having various land covers and geologies. These high yields of phosphorus appear to be related primarily to the percentage of agriculture and the amount of industrial and municipal discharge in a subbasin. The mean annual yield of total suspended solids varied greatly across the study area, and ranged from 28.94 to $1,456.95$ (pounds/acre)/year. Other high yields of total suspended solids were associated with agriculture and urbanization.

\section{INTRODUCTION}

Chesapeake Bay is the largest estuary in the United States, draining approximately $64,000 \mathrm{mi}^{2}$ of Delaware, the District of Columbia, Maryland, New York, Pennsylvania, Virginia, and West Virginia. The estuary stretches nearly 200 miles from its origin at the confluence of the Susquehanna, Northeast, and Elk Rivers in northeastern Maryland to its outlet to the Atlantic Ocean in southeastern Virginia. More than 15 million people live within the watershed that includes the large metropolitan centers of Washington D.C., Baltimore, Md., and Hampton Roads, Va. Chesapeake Bay provides thousands of jobs to workers in the fishing and shellfish, recreation, and shipping industries. Its waters and coastal areas support an abundant and diverse wildlife population.

The living resources of Chesapeake Bay have been degraded as a result of increases in the amount of nitrogen and phosphorus compounds (nutrients) and sediment entering streams from dairy and cattle farms, areas of intense agriculture, and urban development in the watershed (U.S. Environmental Protection 
Agency, 1995). An overabundance of algae in the bay that results from elevated nutrient concentrations restricts light penetration, which reduces the extent of submerged aquatic vegetation used by shellfish larva and fish for food and protection. Decay of algal cells depletes the water of dissolved oxygen and can result in the loss of habitat and the death of fish, shellfish, and other aquatic organisms.

In order to address problems related to nutrient increases, the District of Columbia, Maryland, Pennsylvania, and Virginia signed the Chesapeake Bay Agreement in 1987. The agreement commits these States, along with Federal and local agencies, to work toward a 40-percent reduction in controllable nitrogen and phosphorus loads reaching Chesapeake Bay by the year 2000, based on 1985 levels (U.S. Environmental Protection Agency, 1988). Achievement of this goal is predicted to improve the low dissolved-oxygen conditions, reduce the extent and duration of algal blooms, and improve the clarity and water quality of Chesapeake Bay. Long-term monitoring programs in Maryland, Pennsylvania, and Virginia are used to assess the success of nutrient and sediment reduction strategies.

In 1994, the U.S. Geological Survey (USGS), in cooperation with the Virginia Department of Environmental Quality (DEQ), began publishing periodic reports on the loads and trends of selected nutrients and suspended solids at Fall Line stations on five major Virginia tributaries to the Chesapeake Bay (Bell and others, 1996; Belval and Campbell, 1996; Belval and others, 1994, 1995). (The Fall Line marks the boundary between the Piedmont Physiographic Province and the Coastal Plain Physiographic Province and generally represents the upstream reach of tides.) This report is a continuation of that series and is expanded to include an additional 30 stations above the Fall Line and a discussion of the spatial distribution and temporal changes in concentrations, loads, yields, and trends.

\section{Purpose and Scope}

The purpose of this report is to describe the spatial relations among selected nutrients and suspended solids in streams and land cover, geology, and physiography in the non-tidal parts of five large river basins in the Virginia part of the Chesapeake Bay watershed. This report will also help to identify data limitations and additional monitoring needs.
The water-quality data presented here are derived from analyses of water samples collected from streams in the five basins between 1985 and 1996 by the USGS and the Virginia DEQ. Summary statistics of the concentrations, annual loads, annual yields, and flow-adjusted trends of selected nutrients and suspended solids were calculated for 35 stations. The percentages of land cover, bedrock geology, and physiography were determined for the drainage basin above each station and used to assess spatial differences in nutrients and suspended solids.

\section{Description of Study Basins}

The study area was divided into five major river basins for analysis: Shenandoah/Upper Potomac, Lower Potomac, Rappahannock, York, and James. Loads were calculated for any non-tidal river waterquality monitoring station in these basins for which both continuous-flow records and concentration data were available; 35 stations met these criteria. The major river basins were then divided into subbasins, which represent the drainage area of each of the 35 load stations. The major river basins, subbasins, and load stations are shown in figure 1 . The load station number, concentration station number, and USGS flow station number; the subbasin area; and the station name for each subbasin are summarized by major river basin in table 1 .

Sixteen of the 35 load stations are located in the Shenandoah/Upper Potomac River Basin, the second largest major river basin in the study area. The Shenandoah/Upper Potomac River Basin lies in the Appalachian Mountains and consists of a series of long valleys and ridges oriented southwest-northeast. Two large rivers drain the watershed, the North Fork Shenandoah River and the South Fork Shenandoah River. The area of the South Fork Shenandoah River Basin is twice that of its northern counterpart. The two forks converge several miles northeast of the city of Front Royal to form the Shenandoah River, which drains into the Potomac River. Opequon Creek drains directly into the Potomac River, and stations in that subbasin are included in the analysis of the Shenandoah/Upper Potomac River Basin.

The Lower Potomac River Basin is represented by a single load station (LP1 on figure 1 and table 1) located on Difficult Run near Great Falls, Va. The stream flows through parts of the Northern Virginia suburbs of Manassas, Fairfax, and Vienna. A large 

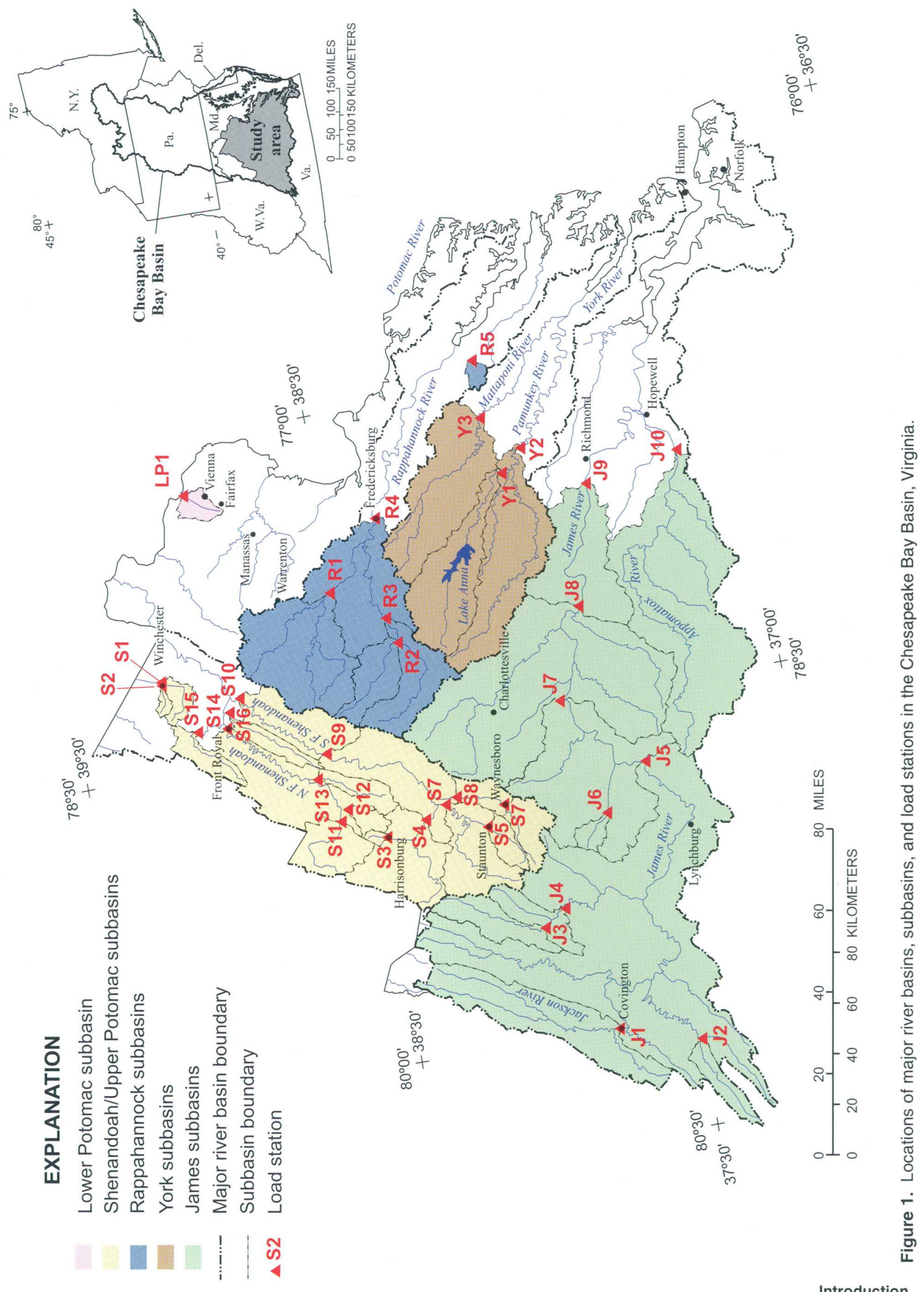
Table 1. Location of load stations in the Chesapeake Bay Basin, Virginia

[DEQ, Virginia Department of Environmental Quality; USGS, U.S. Geological Survey; mi $^{2}$, square miles]

\begin{tabular}{|c|c|c|c|c|c|}
\hline $\begin{array}{l}\text { Load } \\
\text { Station } \\
\text { number }\end{array}$ & $\begin{array}{l}\text { Concentration } \\
\text { station } \\
\text { number }\end{array}$ & Source & $\begin{array}{l}\text { Flow } \\
\text { station } \\
\text { number }\end{array}$ & $\begin{array}{l}\text { Area } \\
\left(\mathbf{m i}^{2}\right)\end{array}$ & Station name and location \\
\hline \multicolumn{6}{|c|}{ Shenandoah/Upper Potomac River Basin } \\
\hline $\mathrm{S} 1$ & 1AOPE036.13 & DEQ & 01615000 & 58 & Opequon Creek near Berryville \\
\hline $\mathrm{S} 2$ & 1AABR000.78 & DEQ & 01616000 & 17 & Abrams Creek near Winchester \\
\hline S3 & 1BMDD005.81 & DEQ & 01621050 & 14 & Muddy Creek at Mount Clinton \\
\hline S4 & 1BNTH014.08 & DEQ & 01622000 & 377 & North River near Burketown \\
\hline S5 & 1BCST012.32 & DEQ & 01624800 & 74 & Christians Creek near Fishersville \\
\hline S6 & 1BMDL001.83 & DEQ & 01625000 & 372 & Middle River near Grottoes \\
\hline S7 & 1BSTH027.85 & DEQ & 01626000 & 127 & South River near Waynesboro \\
\hline S8 & 1BSTH007.80 & $\mathrm{DEQ}$ & 01627500 & 212 & South River at Harriston \\
\hline s9 & IBSSF054.20 & $\mathrm{DEQ}$ & 01629500 & 1,378 & South Fork Shenandoah River near Luray \\
\hline $\mathrm{S} 10$ & 1BSSF003.56 & DEQ & 01631000 & 1,638 & South Fork Shenandoah River at Front Royal \\
\hline S11 & 1BNFS093.53 & DEQ & 01632000 & 196 & North Fork Shenandoah River at Cootes Store \\
\hline $\mathrm{S} 12$ & 1BLNV001.22 & DEQ & 01632082 & 45 & Linville Creek at Broadway \\
\hline $\mathrm{S} 13$ & 1BSMT004.60 & DEQ & 01632900 & 93 & Smith Creek near New Market \\
\hline $\mathrm{S} 14$ & 1BNFS010.34 & $\mathrm{DEQ}$ & 01634000 & 755 & North Fork Shenandoah River near Strasburg \\
\hline $\mathrm{S} 15$ & 1BCDR013.29 & DEQ & 01634500 & 102 & Cedar Creek near Winchester \\
\hline S16 & 1BPSG001.36 & DEQ & 01635500 & 87 & Passage Creek near Buckton \\
\hline \multicolumn{6}{|c|}{ Lower Potomac River Basin } \\
\hline LP1 & 1ADIF000.86 & DEQ & 01646000 & 58 & Difficult Run near Great Falls \\
\hline \multicolumn{6}{|c|}{ Rappahannock River Basin } \\
\hline$\overline{\mathrm{RI}}$ & 3-RPP147.10 & DEQ & 01664000 & 621 & Rappahannock River at Remington \\
\hline $\mathrm{R} 2$ & 3-ROB001.90 & $\mathrm{DEQ}$ & 01666500 & 183 & Robinson River near Locust Dale \\
\hline R3 & 3-RAP030.21 & DEQ & 01667500 & 468 & Rapidan River near Culpepper \\
\hline R4 & 01668000 & USGS & 01668000 & 1,598 & Rappahannock River near Fredericksburg \\
\hline R5 & 3-PIS009.24 & DEQ & 01669000 & 28 & Piscataway Creek near Tappahannock \\
\hline \multicolumn{6}{|c|}{ York River Basin } \\
\hline $\bar{Y} 1$ & 8-NAR005.42 & DEQ & 01671020 & 463 & North Anna River at Hart Corner \\
\hline $\mathrm{Y} 2$ & 01673000 & USGS & 01673000 & 1,080 & Pamunky River near Hanover \\
\hline Y3 & 01674500 & USGS & 01674500 & 603 & Mattaponi River near Beulahville \\
\hline \multicolumn{6}{|c|}{ James River Basin } \\
\hline $\mathrm{J} 1$ & 2-JKS023.61 & DEQ & 02013100 & 584 & Jackson River below Dunlap Creek at Covington \\
\hline $\mathrm{J} 2$ & 2-JOB000.39 & $\mathrm{DEQ}$ & 02017500 & 105 & Johns Creek at New Castle \\
\hline $\mathrm{J} 3$ & 2-CFP004.67 & DEQ & 02020500 & 188 & Calfpasture River above Mill Creek at Goshen \\
\hline $\mathrm{J} 4$ & 2-MRY038.10 & DEQ & 02021500 & 330 & Maury River at Rockbridge Baths \\
\hline J5 & 2-JMS229.14 & DEQ & 02026000 & 3,617 & James River at Bent Creek \\
\hline J6 & 2-PNY005.29 & DEQ & 02027500 & 48 & Piney River at Piney River \\
\hline J7 & 2-JMS 189.31 & DEQ & 02029000 & 4,520 & James River at Scottsville \\
\hline $\mathrm{J} 8$ & 02035000 & USGS & 02035000 & 6,193 & James River at Cartersville \\
\hline J9 & 2-JMS117.35 & DEQ & 02037500 & 6,696 & James River near Richmond \\
\hline $\mathrm{J} 10$ & 02041650 & USGS & 02041650 & 1,344 & Appomattox River at Matoaca \\
\hline
\end{tabular}


percentage of this subbasin is urban land. Although water-quality data are collected at a number of other stations in the Lower Potomac River Basin, continuous-flow data were not available for the time period covered by this study.

The Rappahannock River Basin is the first major river basin south of the Potomac River Basin. The Rappahannock River Basin is predominately rural, but water-quality issues specific to urban development will become increasingly important as rapid expansion around the cities of Fredericksburg and Warrenton continues. The Rappahannock River Basin is represented by five load stations - four stations (R1-R4) are on streams that drain areas of the eastern Blue Ridge and Piedmont Physiographic Provinces, and one station (R5) is on a stream that drains a small upland area in the Coastal Plain.

The York River Basin consists of two separate, smaller basins, the Mattaponi River Basin and the Pamunkey River Basin, whose rivers join to form the York River downstream from the study area. Nearly 70 percent of this major basin is covered by forest and about 20 percent is classified as agricultural land. Unlike the other basins in the study area, the York River Basin contains significant percentages of barren land, open water, and wetlands. The Mattaponi River, the more northerly and smaller of the two rivers, is represented by a single load station (Y3) near the town of Beulahville. The Pamunkey River Basin contains two load stations, one (Y1) on the North Anna River, located about 25-river mi downstream from Lake Anna, and another (Y2) on the Pamunkey River near the town of Hanover. No major cities lie within either the Mattaponi or the Pamunkey River Basins; although the southern Pamunkey River Basin is becoming increasingly developed as the suburbs of Richmond expand northward.

The James River Basin is the largest and most southerly of the basins selected for this study. This basin is also the most varied in terms of geology and physiography. The James River originates in the Appalachian Mountains near the West Virginia border, flows through the Richmond metropolitan area, and joins the Chesapeake Bay near the cities of Hampton and Norfolk in southeastern Virginia. The farthest downstream station on the James River (J9) is just upstream from the city from Richmond. The Appomattox River joins the James River downstream from Richmond near the city of Hopewell, and it is included with the discussion of the James River Basin.

\section{Previous Studies}

Nutrient loads within the Chesapeake Bay watershed were calculated by a number of earlier investigators. Cohn and others (1992) estimated loads entering Chesapeake Bay from the Choptank, Patuxent, Potomac, and Susquehanna Rivers in Maryland with the use of a seven-parameter, log-linear-regression model, which incorporates the Minimum Variance Unbiased Estimator developed by Bradu and Mundlak (1970). Belval and Campbell (1996) and Bell and others (1996) have used the same method to estimate loads at the Fall Line monitoring stations on the Rappahannock, Mattaponi, Pamunkey, James, and Appomattox Rivers in Virginia. This study uses similar methods to update the loads for these stations and includes an additional 30 non-tidal stations. Langland and others (1995) applied the load estimator model at 127 stations on streams across the Chesapeake Bay watershed and presented a spatial analysis of the results.

\section{Acknowledgments}

The authors would like to thank Frederick Hoffman of the Virginia DEQ, Chesapeake Bay Program, for his assistance and guidance of this program. We also acknowledge the assistance of the following USGS colleagues: Michael J. Langland from the Pennsylvania District office for his computation of many of the loads, Linda C. Darrell from the Maryland District office for her guidance on the load estimator model, and L.I. Briel and Theodore B. Samsel from the Virginia District office for their assistance with data preparation. Finally, we would like to express our gratitude to the numerous field and laboratory personnel at the Virginia DEQ, the Virginia Division of Consolidated Laboratories, and the USGS for their high quality work in the collection and analysis of the data used for this study.

\section{METHODS OF INVESTIGATION}

Concentration and discharge data were used to estimate loads and flow adjusted trends at 35 stations on streams in non-tidal basins in Virginia. Geographic information system (GIS) data layers of land cover, geology, and basin geometry were obtained or generated for the spatial analyses. The following sections 
describe the data sets and methods used to generate data needed for the analyses described later in this report.

\section{Compilation of Water-Quality Data}

The water-quality data set used for this report were compiled from data collected by the USGS/Virginia DEQ Chesapeake Bay River Input Monitoring Program, and from the U.S. Environmental Protection Agency's (EPA) STORET data base. The USGS, in cooperation with the Virginia DEQ, collects water samples during base-flow and stormflow conditions at five stations collectively known as Chesapeake Bay River Input Monitoring (RIM) stations. Data collection at these sites began in 1988 on the Rappahannock and James Rivers and in 1989 on the Mattaponi, Pamunkey, and Appomattox Rivers, and continues today. At each RIM station, approximately 24 base-flow samples and 20 stormflow samples are collected annually. These data are stored in the USGS National Water Information System (NWIS) data base in Richmond, Va. Reports by Belval and others (1994, 1995), and Bell and others (1996) have described the data-collection methods and quality-assurance procedures used to develop the USGS data base.

Data retrieved from EPA's STORET data base that met the following criteria were included in the data set:

1. Nutrient or suspended solids samples collected between October 1, 1984 and December 31, 1996.

2. Data collected during a minimum of 3 -consecutive years.

3. At least 50 samples collected with at least 1 sample from each season.

4. Continuous-discharge data available at the waterquality monitoring station, or continuous-discharge data available within 1,500 yards of the water-quality monitoring station with no significant changes in the hydrology between the two stations.

On the basis of these criteria, 30 stations were selected for analysis. The Virginia DEQ collected all the data retrieved from STORET.

\section{Compilation of Hydrologic Data}

Flow data used in this study were collected at streamflow-gaging stations operated and maintained by the USGS or the Virginia DEQ using methods described in Rantz and others (1982) and conforming to USGS standards. Daily mean values of flow were used with the concentration data set as input to the load estimator model.

\section{Estimation of Loads}

Loads of nutrients and suspended solids were estimated using the seven-parameter, log-linearregression model developed by Cohn and others (1989). The model uses the Minimum Variance Unbiased Estimator (MVUE) developed by Bradu and Mundlak (1970) to correct for the bias introduced when the data is transformed from "log space" back into "real space." The MVUE regression model has been used to estimate loads in a number of other investigations in the Chesapeake Bay Basin region (Cohn and others, 1992; Belval and Campbell, 1996; Bell and others, 1996). The model calculates the standard deviation for each estimated load, which was used to calculate a 95-percent confidence interval for that load. Annual loads having confidence values in excess of 80 percent of the estimated load were not used in the analyses. The reader is referred to the above references for a more detailed description of the model. A complete list of the annual loads and errors used for this study is available in Langland and others (1998).

The accuracy of the regression produced by the MVUE regression model is affected greatly by the quality of the data set. The model will work best with at least 50 concentration values from samples collected during a 3-year period. The regression model generally will produce a better fit to the data if a longer period of record and a larger number of samples are available. Availability of values for samples collected during the full range of observed flow conditions also will greatly enhance the accuracy of the model.

Too few, or a lack of, samples collected during high streamflow conditions can result in a significant error in the estimated load. If samples have been collected only during low and moderate streamflows, the relation developed between concentration and flow will be representative of only those flow conditions. This relation must then be extrapolated to estimate 
concentrations for higher streamflows. Because the regression is performed on log-transformed values of concentration and streamflow, a small change in the slope of the regression line can result in a large change in the extrapolated value. An underestimate or overestimate of the extrapolated concentration value can result.

An example of this problem was discovered in comparing the estimated annual loads of total suspended solids for the James River at Cartersville (J8) to the values estimated for the James River at Richmond (J9). The Richmond station is about 40-river mi downstream from the Cartersville station. No appreciable changes in land cover or geology occur and no major tributaries or point source discharges enter the James River between the two stations. Thus, loads of nutrient and suspended solids loads at the two stations should be similar, and indeed, the estimated loads at the two stations for low-to-moderate streamflow years, such as 1989-95, agree reasonably well (fig. 2). However, during exceptionally high streamflow years, such as 1996 when daily discharge was as high as 130,000 $\mathrm{ft}^{3} / \mathrm{s}$, the estimated suspended solids load was significantly larger at the Richmond station. The estimated loads between the two stations probably differ because the regression was fit to the available data, and values of concentration for high-flow conditions must be extrapolated from this relation. More high-flow samples have been collected at Cartersville than at Richmond. For 1996, the 10 largest concentration values of total suspended solids collected at the Cartersville station ranged from 446 to $800 \mathrm{mg} / \mathrm{L}$ and had corresponding discharges ranging from 16,700 to 130,000 $\mathrm{ft}^{3} / \mathrm{s}$. In contrast, the 10 largest concentration values collected at the Richmond station ranged from 69 to $286 \mathrm{mg} / \mathrm{L}$ and had corresponding discharges ranging from 8,870 to $58,700 \mathrm{ft}^{3} / \mathrm{s}$.

The undersampling of high streamflow conditions is expected to result in smaller errors in estimated loads of total nitrogen and total phosphorus because (1) concentrations of those are much smaller than for suspended solids and (2) the range of concentrations of nitrogen and phosphorus is much smaller than the range of concentrations of total suspended solids. An example of probable underestimation of total nitrogen loads at the Richmond station (J9) is depicted in figure 3 .

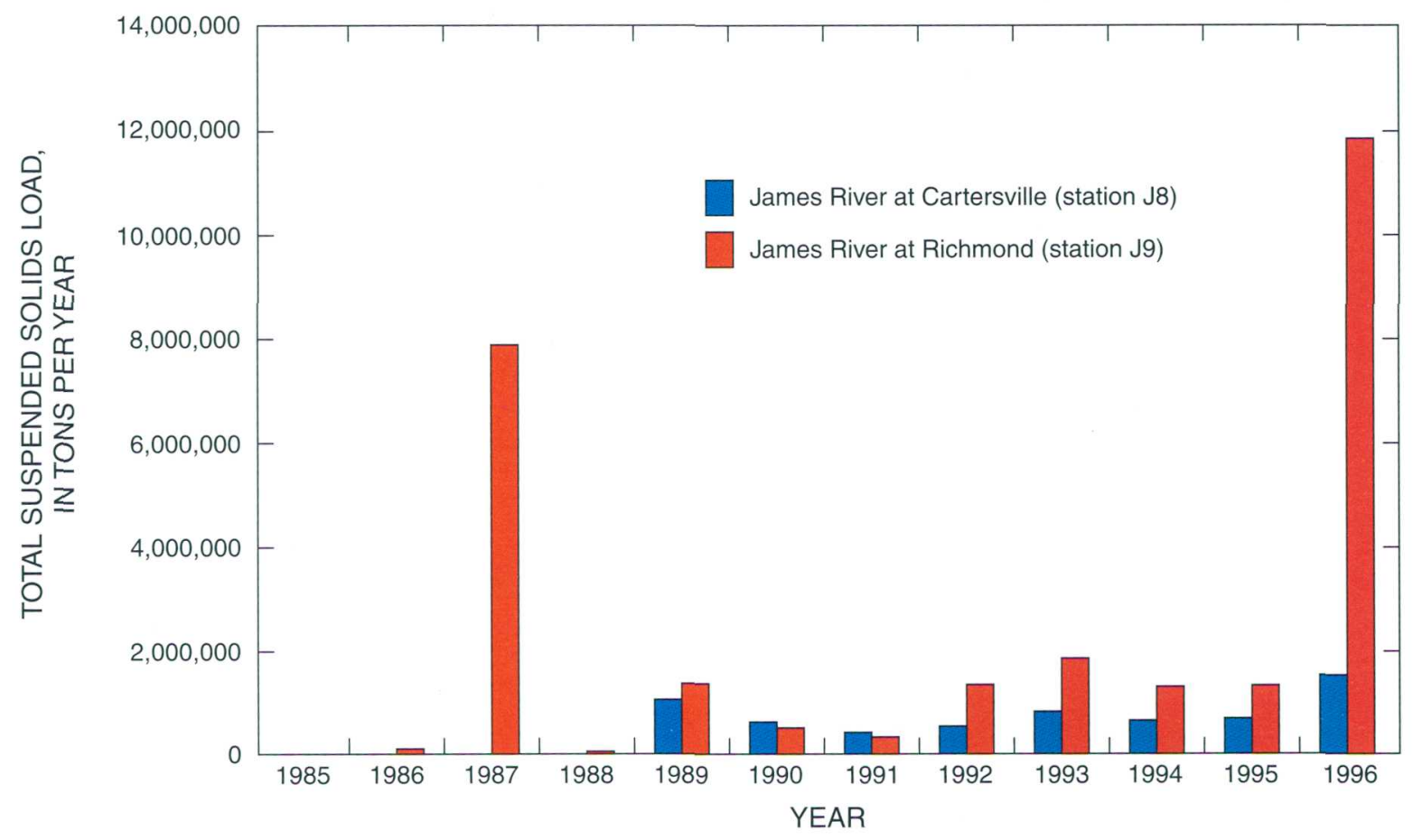

Figure 2. Difference in the calculated annual loads of total suspended solids for the James River at Cartersville and the James River at Richmond. (The Cartersville site has data for a large range of flow conditions, whereas the Richmond site has data for a limited range of flow conditions.) 


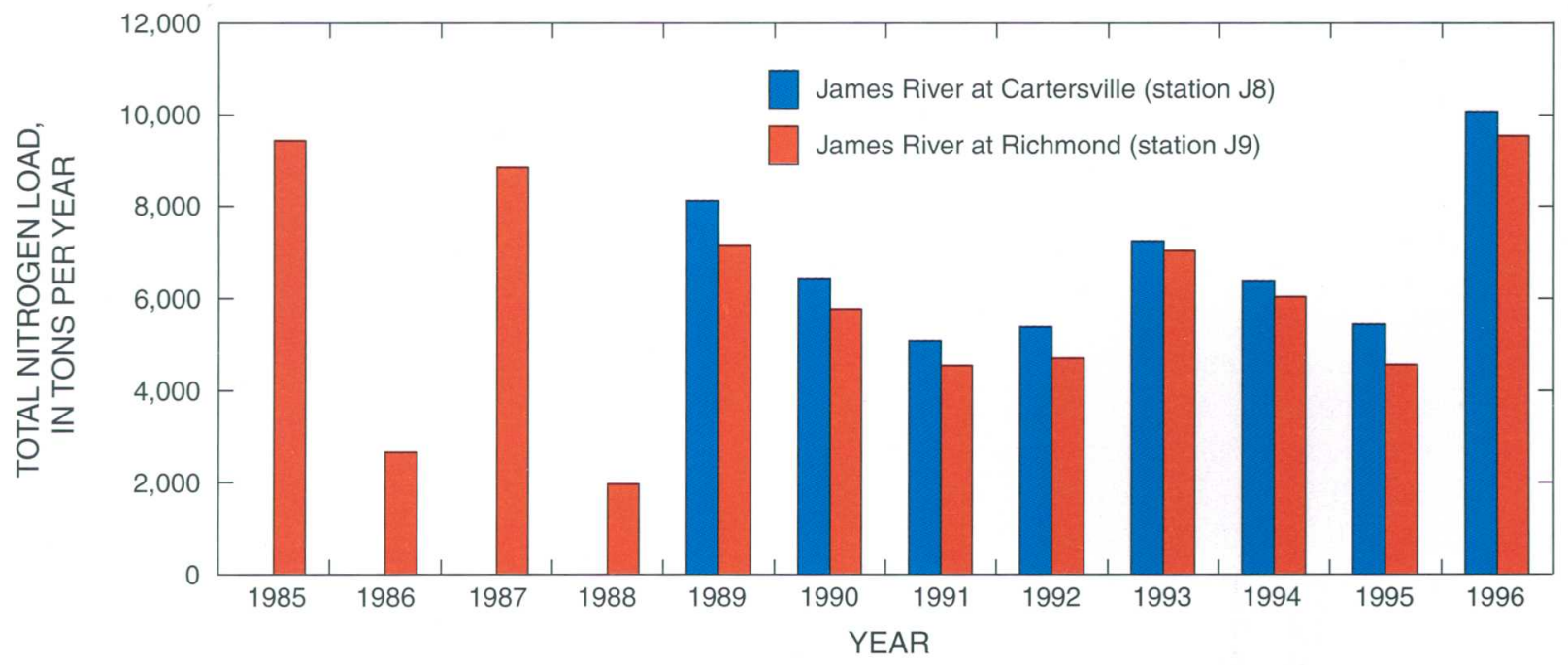

Figure 3. Difference in the calculated annual loads of total nitrogen for the James River at Cartersville and the James River at Richmond. (The Cartersville site has data for a large range of flow conditions, whereas the Richmond site has data for a limited range of flow conditions.)

\section{Estimation of Trends}

Because the concentration of nutrients and suspended solids in a river generally fluctuates with flow conditions, evaluating long-term changes in nutrient and suspended solids is difficult by simply viewing a time series of raw concentration data. One method of evaluating long-term changes of nutrients and suspended solids input to a river is by computing a flow-adjusted trend in concentration. For this report, the method for computing flow-adjusted trends described by Bell and others (1996) is used. The decimal time coefficient $\left(\beta_{3}\right)$ from the load estimator model and the period of record $(t)$ are substituted into the following equation to obtain the trend:

$$
\text { Trend in percent }=100\left(e^{\beta_{3} t}-1\right) \text {. }
$$

Trends were calculated for all constituents for which a load was determined and are expressed as a percent change during the period of record $(t)$. A positive trend indicates that an increase in the concentration of a constituent would be observed during the period of record, if flow were constant throughout that period. A negative trend indicates that a decrease in the concentration of a constituent would be observed during a constant-flow period. The probability that a computed trend is real and not caused by random variations in the data is measured by the probability value ( $p$-value) of the decimal time coefficient, $\beta_{3}$. For example, a p-value of 0.05 would mean that there is a 95-percent chance that the trend computed for some value of $\beta_{3}$ truly exists in the data and is not a result of random variations. A p-value of 0.09 for that same $\beta_{3}$ would mean that there is a 91-percent chance that the computed trend is real. Additional description of trend calculations from the MVUE regression model can be found in Bell and others (1996).

\section{Compilation of Spatial Data}

The geology data layer used for this study was a GIS polygon coverage of formation contacts. The geology and physiography data layers were intersected and grouped into regions, referred to as litho-physiographic regions, or LPR's, where the hydrologic system and water chemistry are expected to be similar. In defining the LPR's, formation contacts were given precedence over physiographic province boundaries. 
Table 2. Definitions of litho-physiographic regions in the Chesapeake Bay Basin, Virginia

\begin{tabular}{|c|c|}
\hline Litho-physiographic region & Lithologic and physiographic components \\
\hline Coastal Plain & $\begin{array}{l}\text { Tertiary sediments of the Coastal Plain and eastern Piedmont Physio- } \\
\text { graphic Province }\end{array}$ \\
\hline Mesozoic basin fill. . & $\begin{array}{l}\text { Mesozoic rocks and sediment of the Piedmont and eastern Blue Ridge } \\
\text { Physiographic Province }\end{array}$ \\
\hline Piedmont crystalline. & $\begin{array}{l}\text { Early Paleozoic metamorphic and igneous rocks of the Piedmont Physi- } \\
\text { ographic Province and low relief Proterozoic age rocks in the core of } \\
\text { the Blue Ridge Anitclinorium }\end{array}$ \\
\hline Piedmont carbonate . & Marbles of the Piedmont Physiographic Province \\
\hline Blue Ridge . & $\begin{array}{l}\text { Ridge-forming Proterozoic to early Paleozoic metamorphic and igneous } \\
\text { rocks of the Blue Ridge and western Piedmont Physiographic Provinces }\end{array}$ \\
\hline Valley and Ridge carbonate.............. & $\begin{array}{l}\text { Paleozoic sedimentary rock formations with a carbonate component. } \\
\text { West of the Blue Ridge and east of the Appalachian Plateau Physio- } \\
\text { graphic Provinces }\end{array}$ \\
\hline Valley and Ridge siliciclastic. .... & $\begin{array}{l}\text { Paleozoic sedimentary rock formations without a carbonate component. } \\
\text { West of the Blue Ridge and east of the Appalachian Plateau Physio- } \\
\text { graphic Provinces }\end{array}$ \\
\hline
\end{tabular}

Seven different LPR's were identified in the study area (table 2); their distribution among the 35 subbasins is shown in figure 4 .

The land cover data layer used for this study was derived from the EPA Region III Land Cover Data Set Version 2 (U.S. Environmental Protection Agency, 1996). This data layer is a raster grid generated from Landsat mosaic images taken between 1991 and 1993. Land cover is divided into 15 different classes and has a resolution of 30 meters. For this report, the 15 land cover classes were generalized into 6 categories, which are defined in table 3. The generalized land cover for the 35 subbasins is shown in figure 5.

Drainage basin boundaries used for this study were generated from the Virginia Department of Conservation and Recreation Division of Soil and Water Conservation drainage basin coverage (1995). New lines were added to delimit drainage basin boundaries to the 35 load stations.

The litho-physiographic data layer and the land cover data layer were intersected with the subbasin boundaries to determine the percentage of each LPR and land cover within a subbasin. The distribution of land cover and LPR for each subbasin in the study area is provided in table 4 .
Table 3. Consolidation of U.S. Environmental Protection Agency (EPA) land cover classes

\begin{tabular}{|c|c|c|}
\hline $\begin{array}{c}\text { Generalized } \\
\text { land } \\
\text { cover }\end{array}$ & $\begin{array}{c}\text { EPA } \\
\text { class } \\
\text { number }\end{array}$ & $\begin{array}{c}\text { EPA } \\
\text { land cover } \\
\text { class }\end{array}$ \\
\hline \multirow[t]{3}{*}{ Agriculture.... } & 4 & Hay / pasture / grass \\
\hline & 5 & Row crops \\
\hline & 6 & Probable row crops \\
\hline \multirow[t]{3}{*}{ Forest....... } & 7 & Conifer forest \\
\hline & 8 & Mixed forest \\
\hline & 9 & Deciduous forest \\
\hline \multirow[t]{2}{*}{ Urban........ } & 2 & Low intensity developed \\
\hline & 3 & High intensity developed \\
\hline \multirow[t]{2}{*}{ Wetlands } & 10 & Woody wetlands \\
\hline & 11 & Emergent wetlands \\
\hline \multirow[t]{4}{*}{ Barren ....... } & 12 & Quarry areas \\
\hline & 13 & Coal mines \\
\hline & 14 & Beach areas \\
\hline & 15 & Transitional (including clear cuts) \\
\hline Water....... & 1 & Water \\
\hline
\end{tabular}




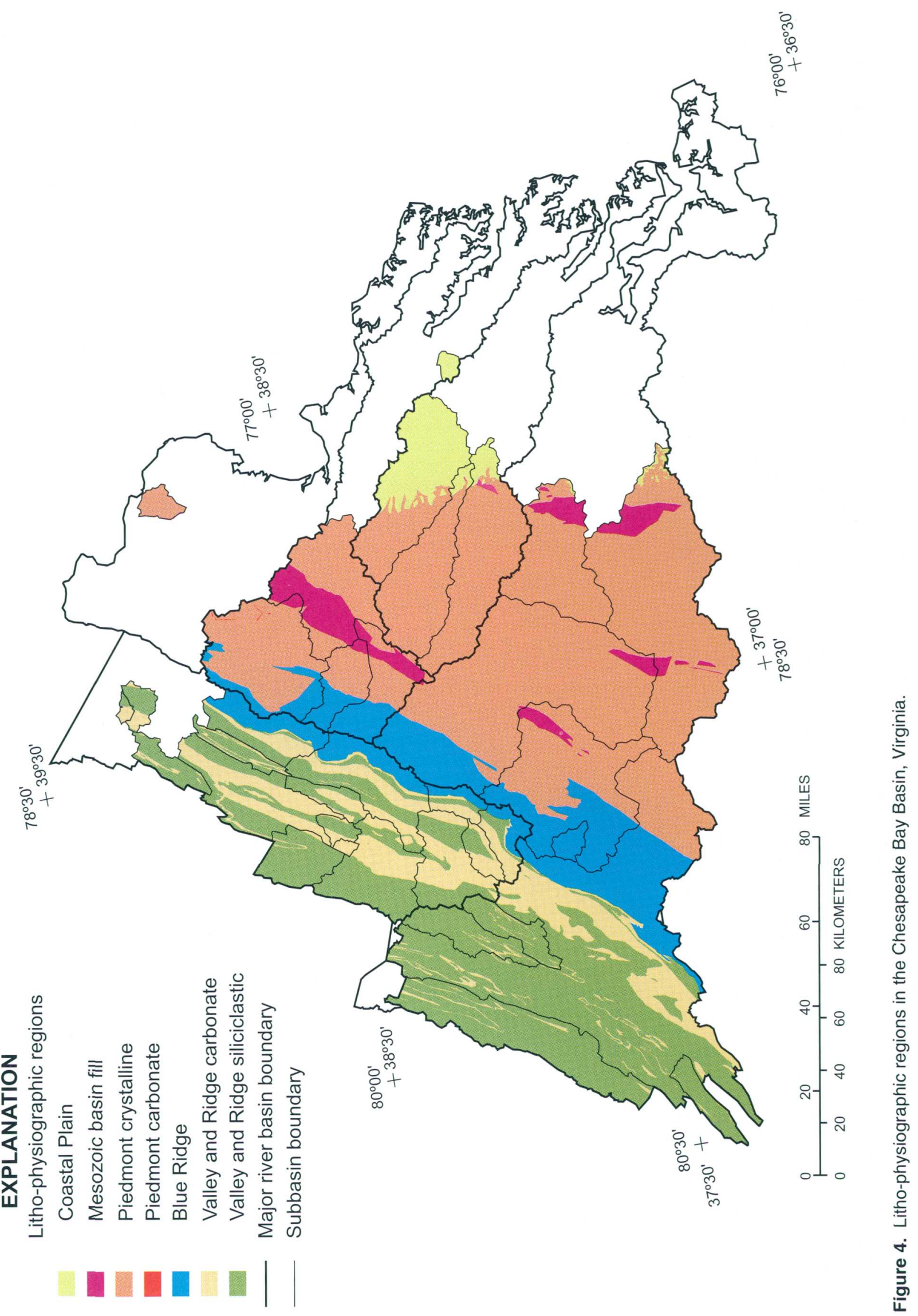




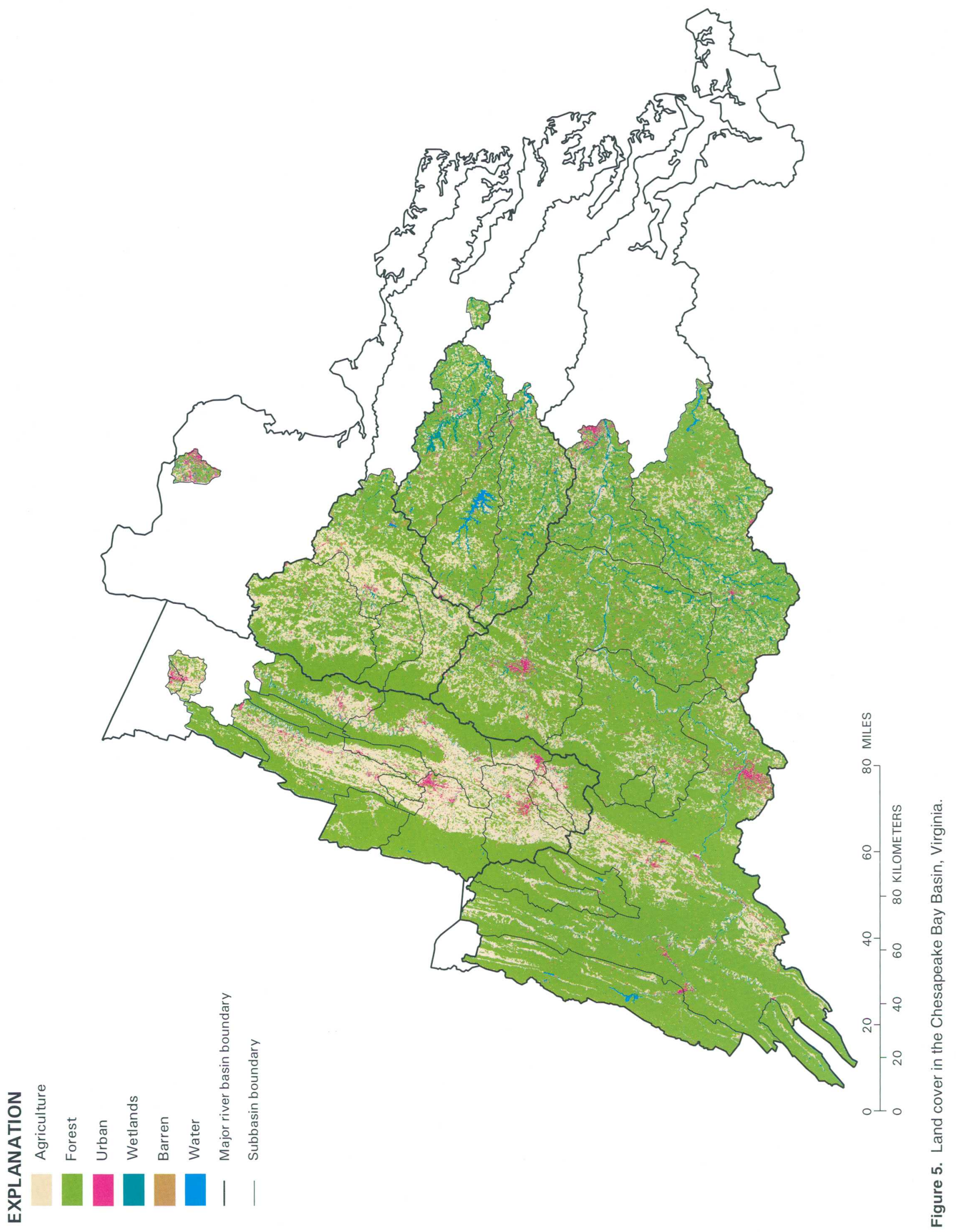




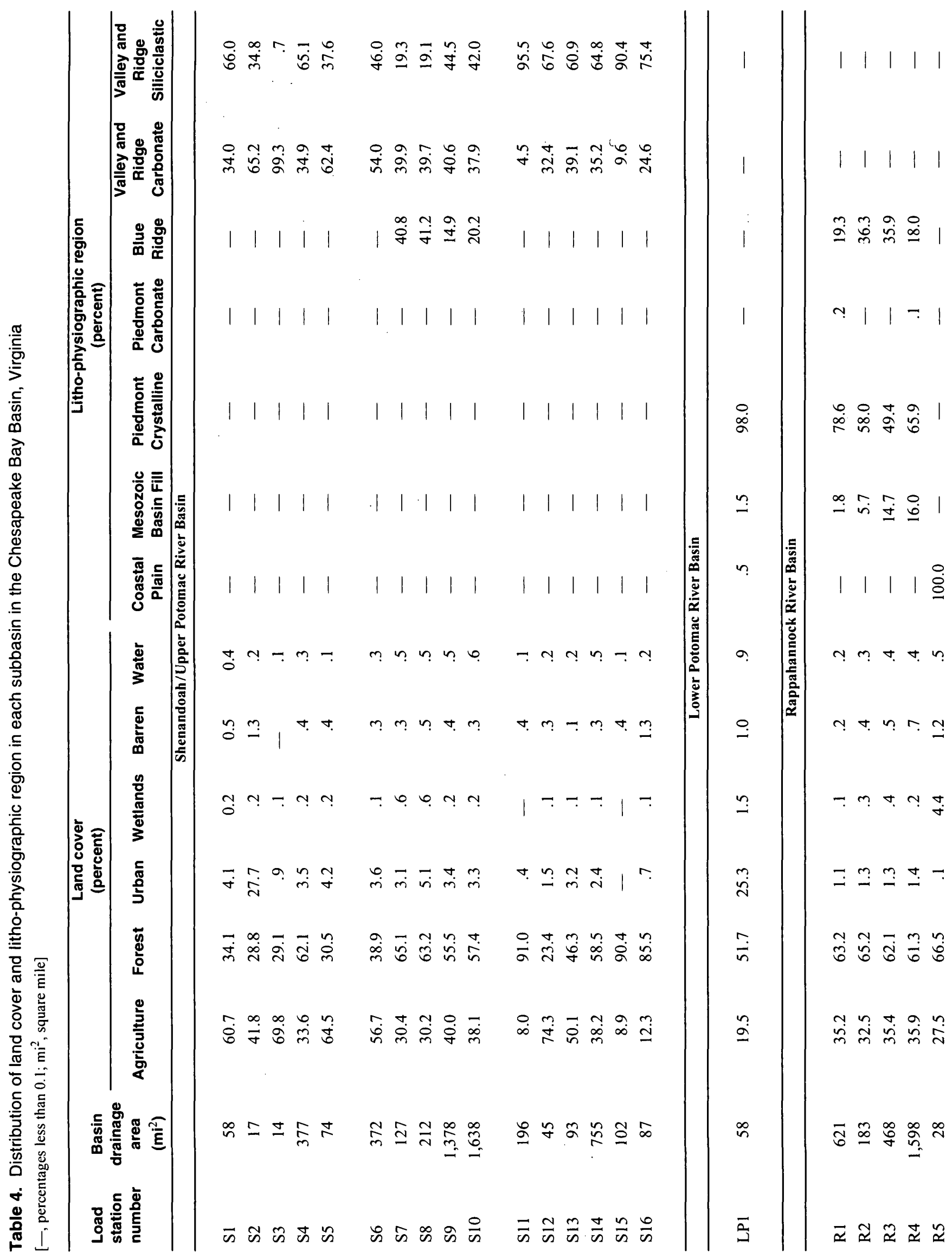




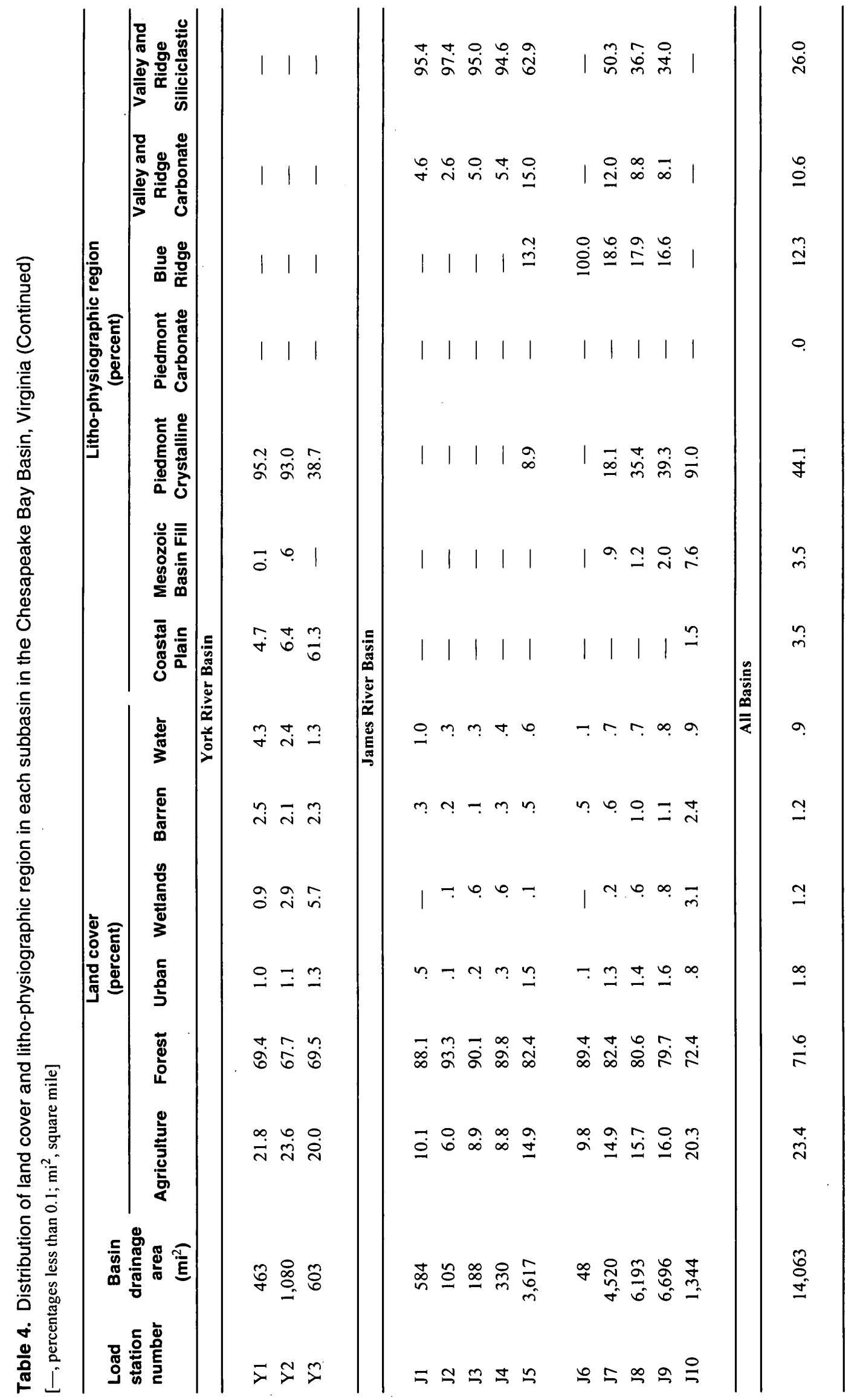




\section{PHYSICAL FACTORS AFFECTING THE DELIVERY OF NUTRIENTS AND SUSPENDED SOLIDS TO RIVERS}

Geology, physiography, and land cover are the primary controls on the delivery of non-point nutrient and suspended solids loads to rivers. Geology controls the delivery of nutrients and suspended solids by: (1) determining the soil mineralogy and, in part, grain size, which determine infiltration rates and the potential for nutrient retention through sorption of chemical binding; (2) determining the distribution of phosphorus bearing rocks that may function as a natural source of this nutrient; and (3) delaying and potentially reducing the delivered load of dissolved nutrients by first routing them through the ground-water system.

Physiography controls the delivery of nutrients and suspended solids by determining the distribution and slope of mountains and valleys that affect rainfall and runoff patterns. Land cover controls the delivery of nutrients and suspended solids by determining: (1) the quantity and type of nutrients that are released into the environment; (2) the speed at which nutrients are taken up from the environment; (3) the quantity and type of nutrients that are stored; (4) the length of time nutrients are store; and (5) the soil retention and erosion rates.

\section{NUTRIENT AND SUSPENDED SOLIDS CONCENTRATIONS}

The distribution of concentrations of total nitrogen, total ammonia, total nitrite, total nitrate, total Kjeldahl nitrogen, total phosphorus, dissolved orthophosphorus, and total suspended solids for each of the 35 load stations in the study area are shown in box plots of the data (figs. 6-10). The median and interquartile range of concentrations for the RIM stations tend to be larger than those for the non-RIM stations because the RIM stations are targeted for stormflow sampling and have nearly the same number of stormflow and base-flow samples.

The highest and most variable concentrations of the different nitrogen species are found in the Shenandoah/Upper Potomac River Basin (fig. 6). In most subbasins in the study area, nitrate is the dominant nitrogen species; however, total Kjeldahl nitrogen tends to be the dominant nitrogen species in subbasins having relatively large percentages of wetland areas, such as the York River Basin (fig. 9) and Piscataway
Creek (station R5, fig. 8) in the Rappahannock River Basin. One notable exception to this pattern is the dominance of organic nitrogen in the Jackson River Basin (station J1, fig. 10), which is 88 percent forested. The dominance of organic nitrogen here may be due to discharges from sewage-treatment and industrial facilities immediately upstream from the sampling site.

With the exception of Jackson River, in the James River Basin, and Abrams Creek (station S2, fig. 6), in the Shenandoah/Upper Potomac River Basin, concentrations of phosphorus generally are less than $0.2 \mathrm{mg} / \mathrm{L}$ across the study area. Both Jackson River and Abrams Creek drain small watersheds that receive large amounts of sewage-treatment plant and industrial discharges. These extreme concentrations are a local phenomenon that dissipates as mixing occurs with waters downstream.

Concentrations of total suspended solids were highest in the Shenandoah/Upper Potomac and James River Basins, but the two basins have different patterns in suspended solids concentrations. In the Shenandoah/Upper Potomac River Basin, the smaller subbasins have the largest ranges and medians of suspended solids concentrations. In contrast, the ranges and medians of suspended solids in the James River Basin increase downstream.

\section{NUTRIENT AND SUSPENDED SOLIDS LOADS}

An annual load for as many as 8 water-quality constituents was estimated at the 35 load stations for a total of 188 station-constituent combinations. Annual loads having an error greater than 80 percent were excluded from the analyses for this report. Loads that were most commonly excluded were those from highflow years, particularly 1987 and 1996.

Mean annual loads generally increased with subbasin area (table 5). Variations in this trend are due primarily to differences in land cover and litho-physiography among the subbasins and because the range of years included in the mean is not consistent from station to station. The three largest mean annual loads of total nitrogen and total phosphorus were estimated for stations $\mathrm{J} 7, \mathrm{~J} 8$, and $\mathrm{J}$, respectively, which represent the three largest subbasins in the study area. The three largest mean annual loads of total suspended solids 
NITROGEN SPECIES
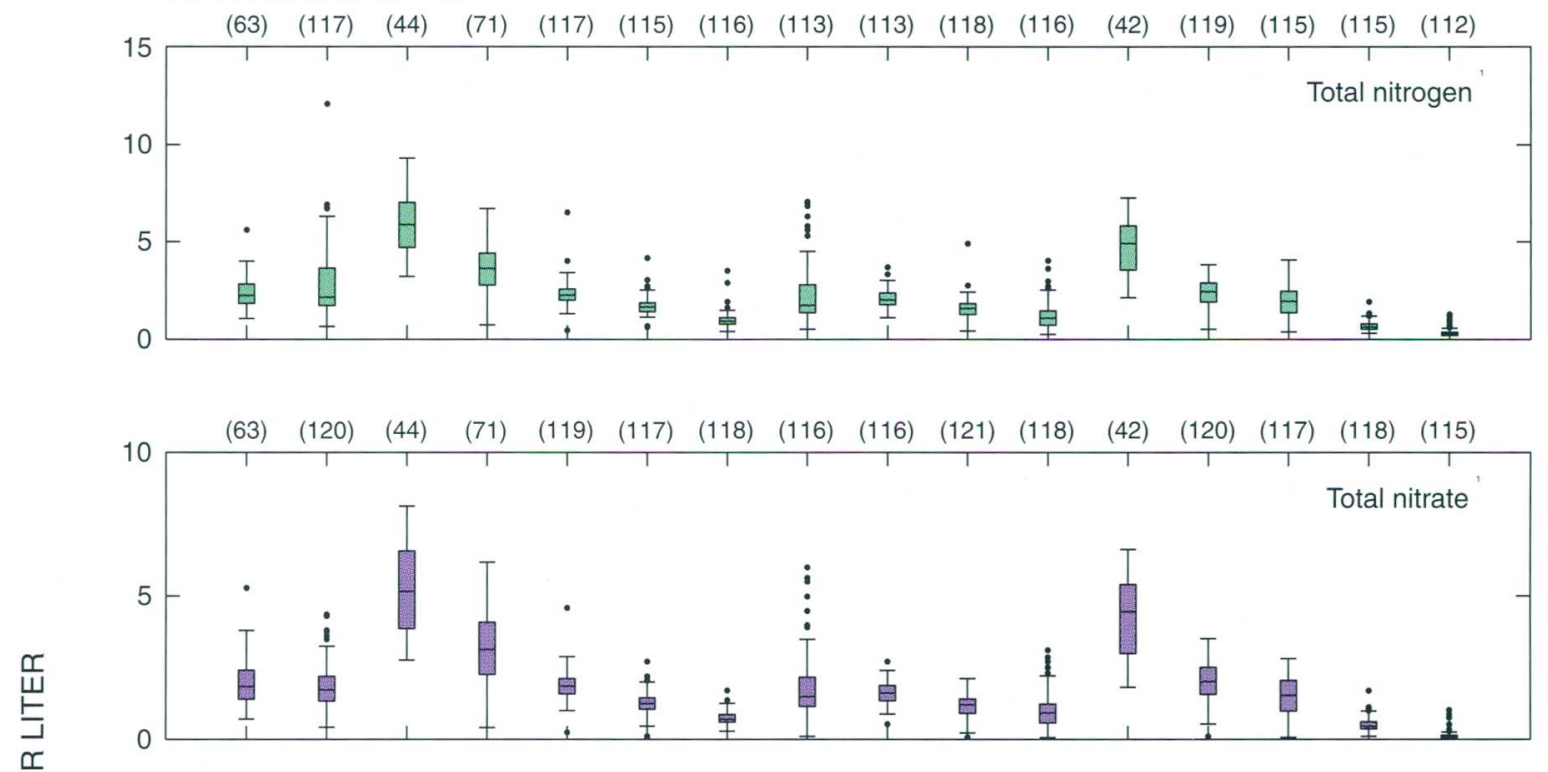

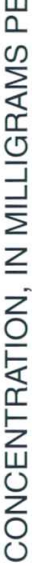
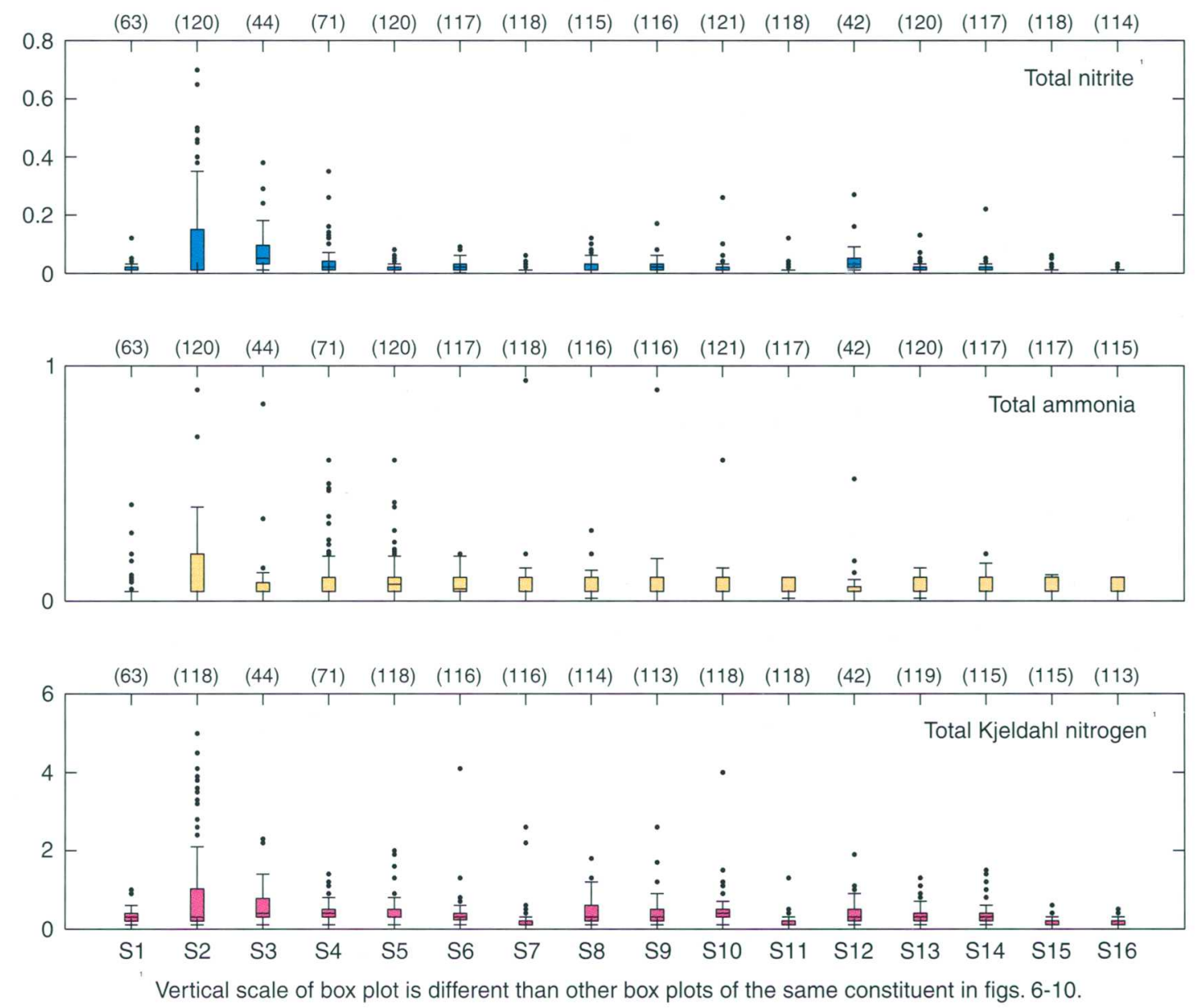

Figure 6. Distribution of concentrations of selected constituents at stations in the Shenandoah / Upper Potomac River Basin, Virginia. 


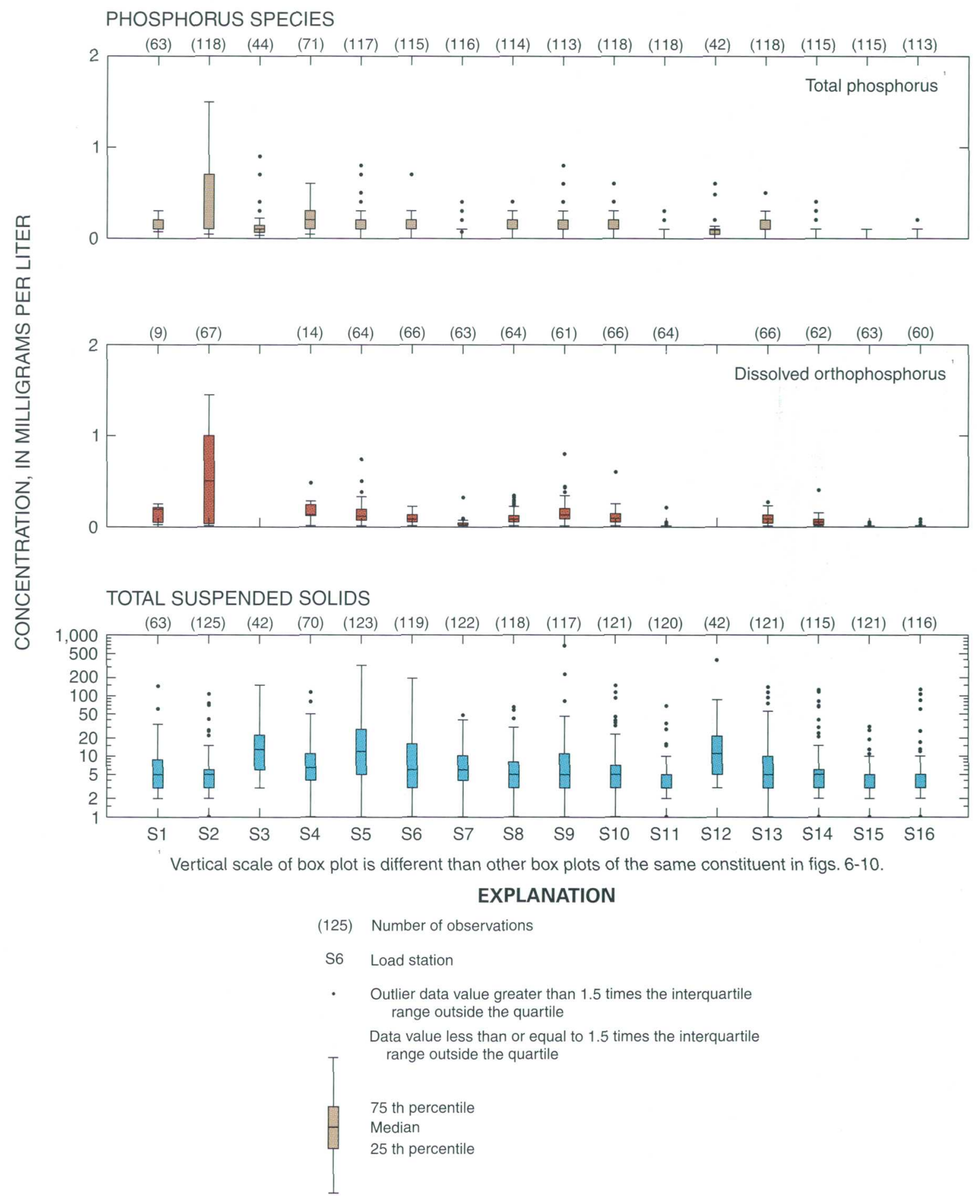

Figure 6.-Continued. 
NITROGEN SPECIES
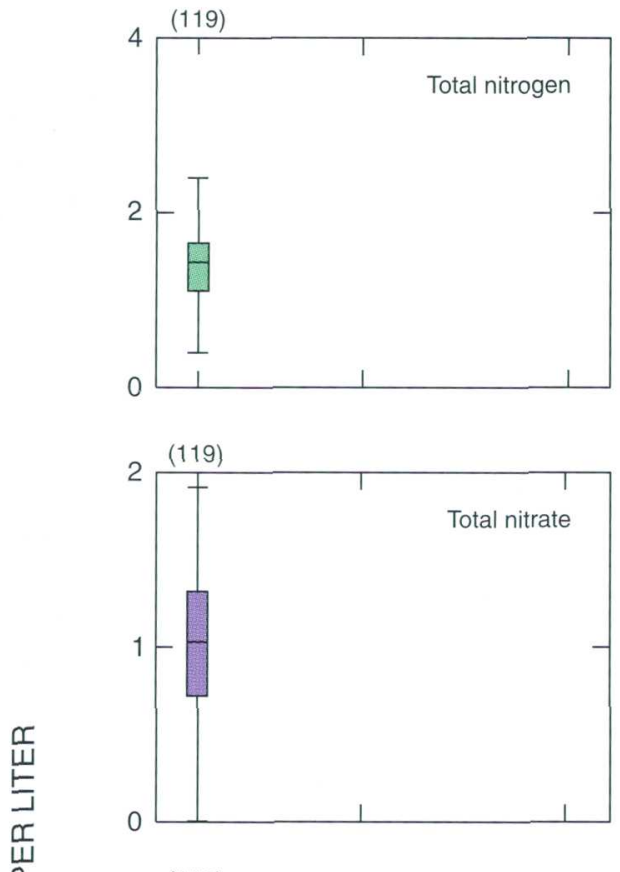

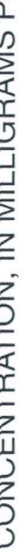
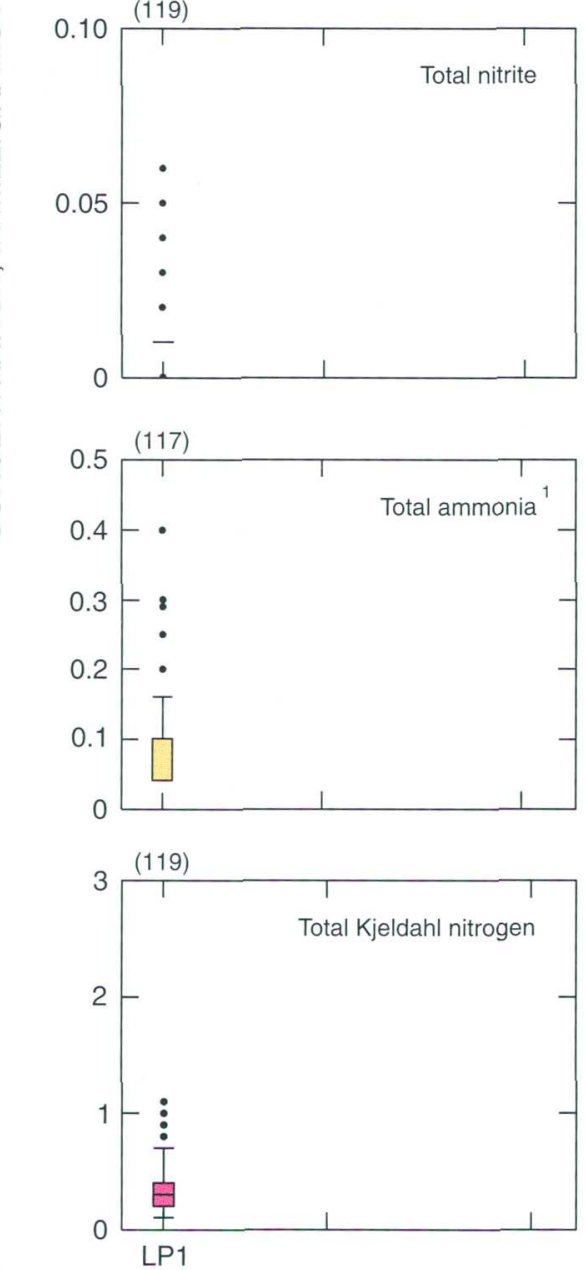

PHOSPHORUS SPECIES
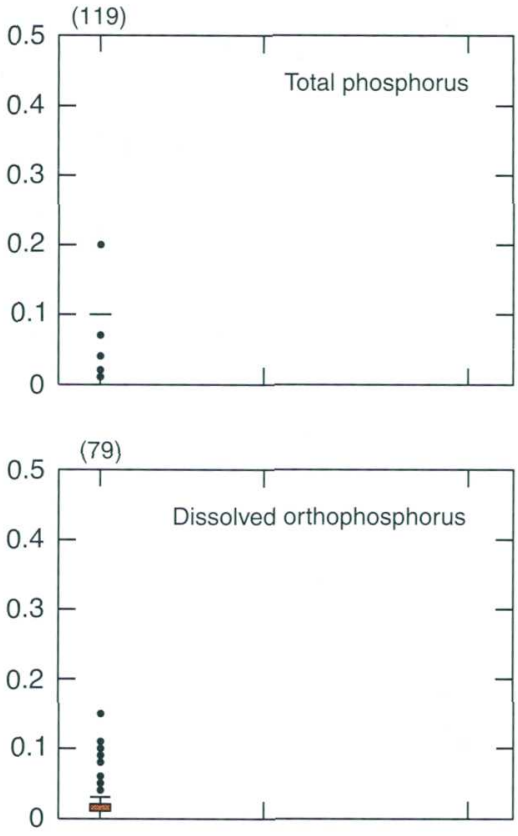

TOTAL SUSPENDED SOLIDS

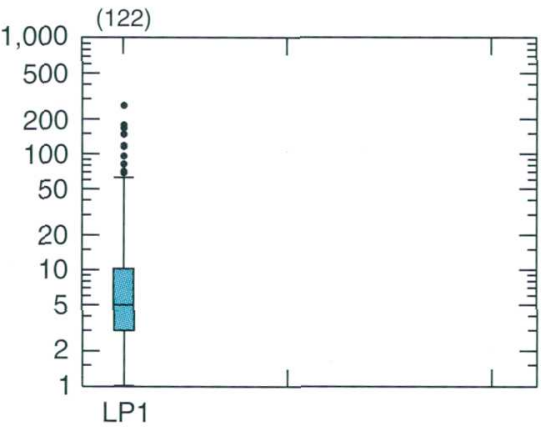

EXPLANATION

(119) Number of observations

LP1 Load station

- $\quad$ Outlier data value greater than 1.5 times the interquartile range outside the quartile Data value less than or equal to

1.5 times the interquartile range outside the quartile 75 th percentile Median

25 th percentile

${ }^{1}$ Vertical scale of box plot is different than other box plots of the same constituent in figs. 6-10.

Figure 7. Distribution of concentrations of selected constituents at stations in the Lower Potomac River Basin, Virginia. 


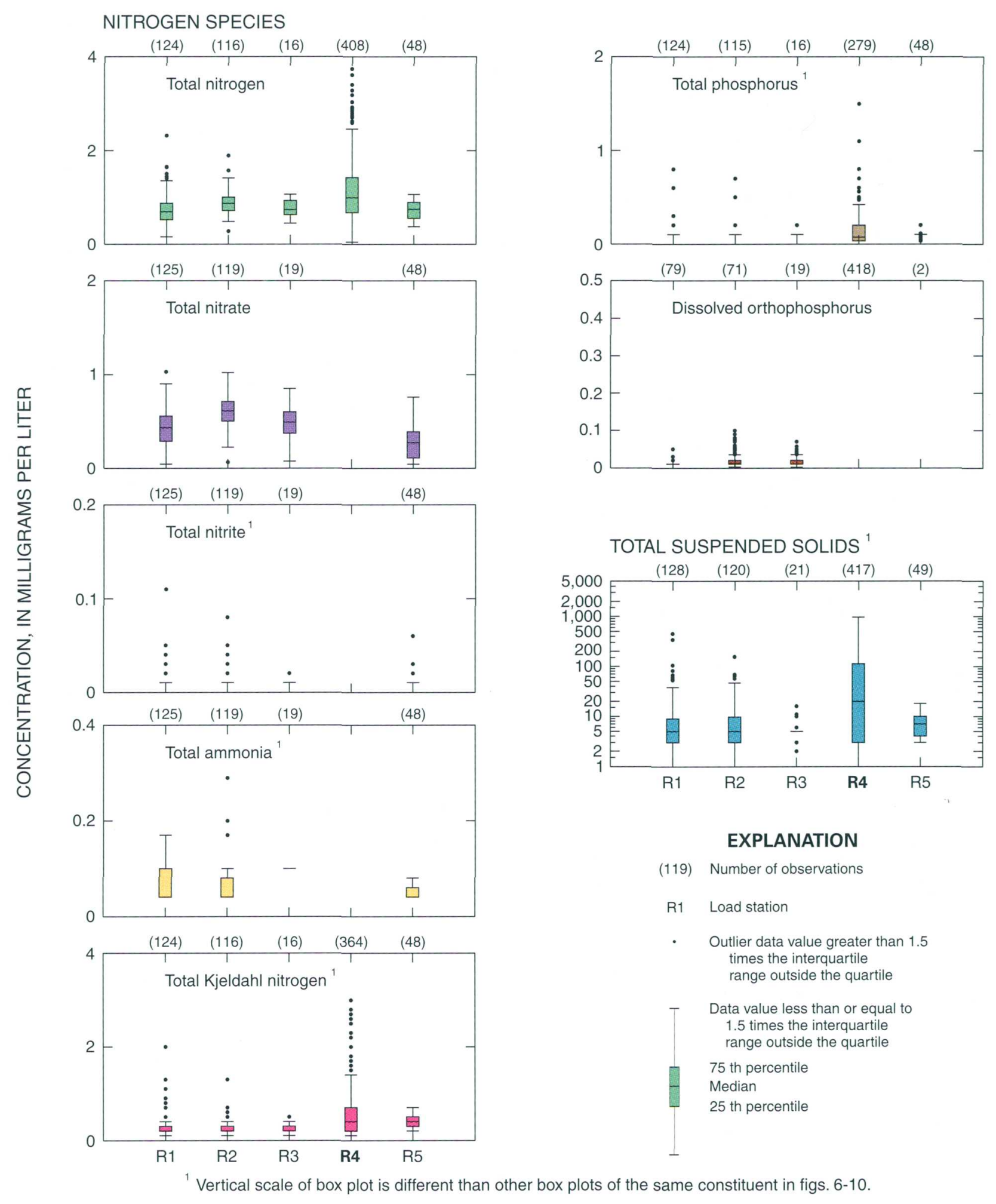

Figure 8. Distribution of selected concentrations of constituents at stations in the Rappahannock River Basin, Virginia. (River input monitoring station is printed in bold type.) 
NITROGEN SPECIES
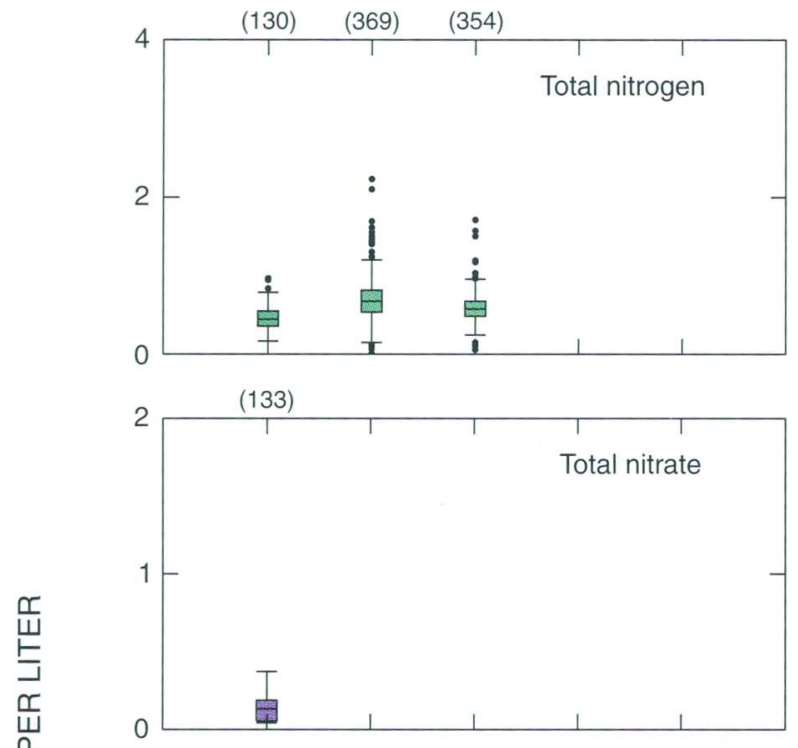

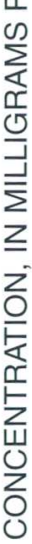

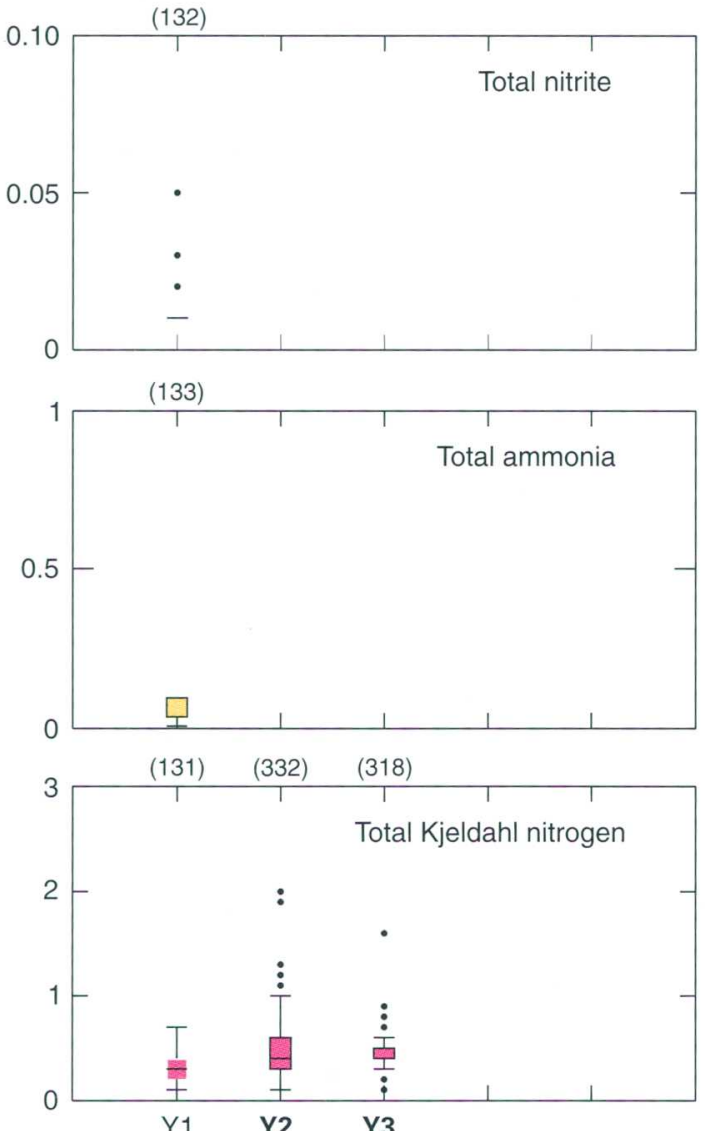

PHOSPHORUS SPECIES
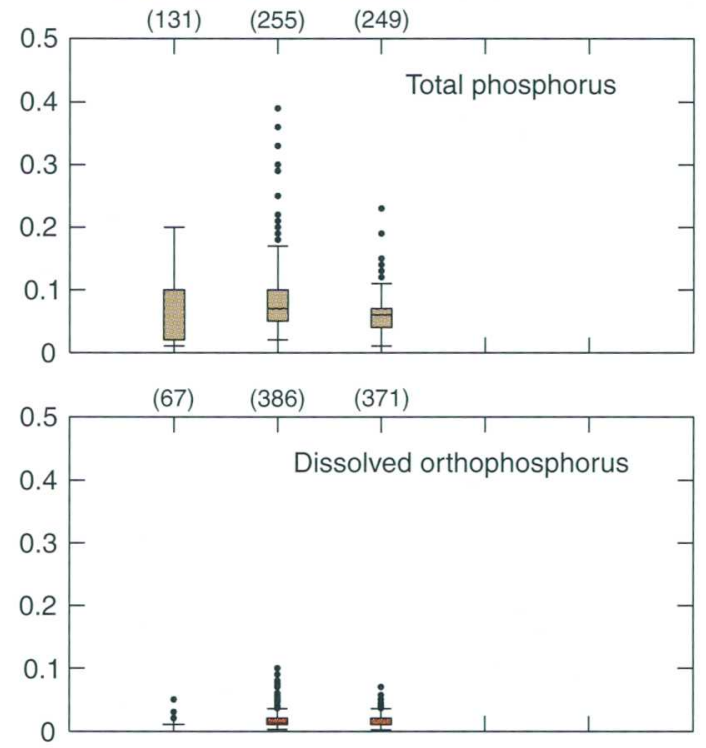

TOTAL SUSPENDED SOLIDS

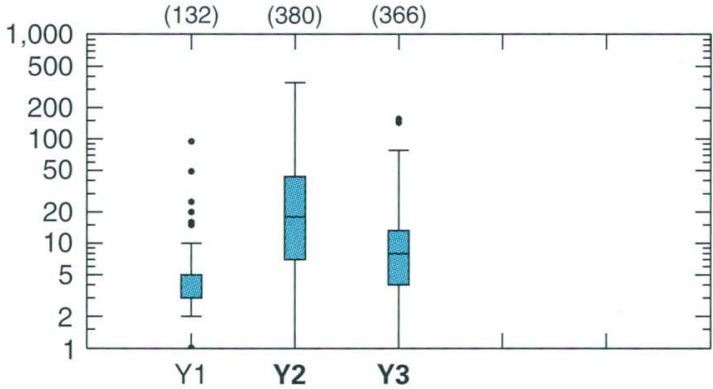

EXPLANATION

(130) Number of observations

Y1 Load station

- $\quad$ Outlier data value greater than 1.5 times the interquartile range outside the quartile

- Data value less than or equal to 1.5 times the interquartile range outside the quartile

75 th percentile

Median

25 th percentile

Figure 9. Distribution of concentrations of selected constituents at stations in the York River Basin, Virginia. (River input monitoring station is printed in bold type.) 


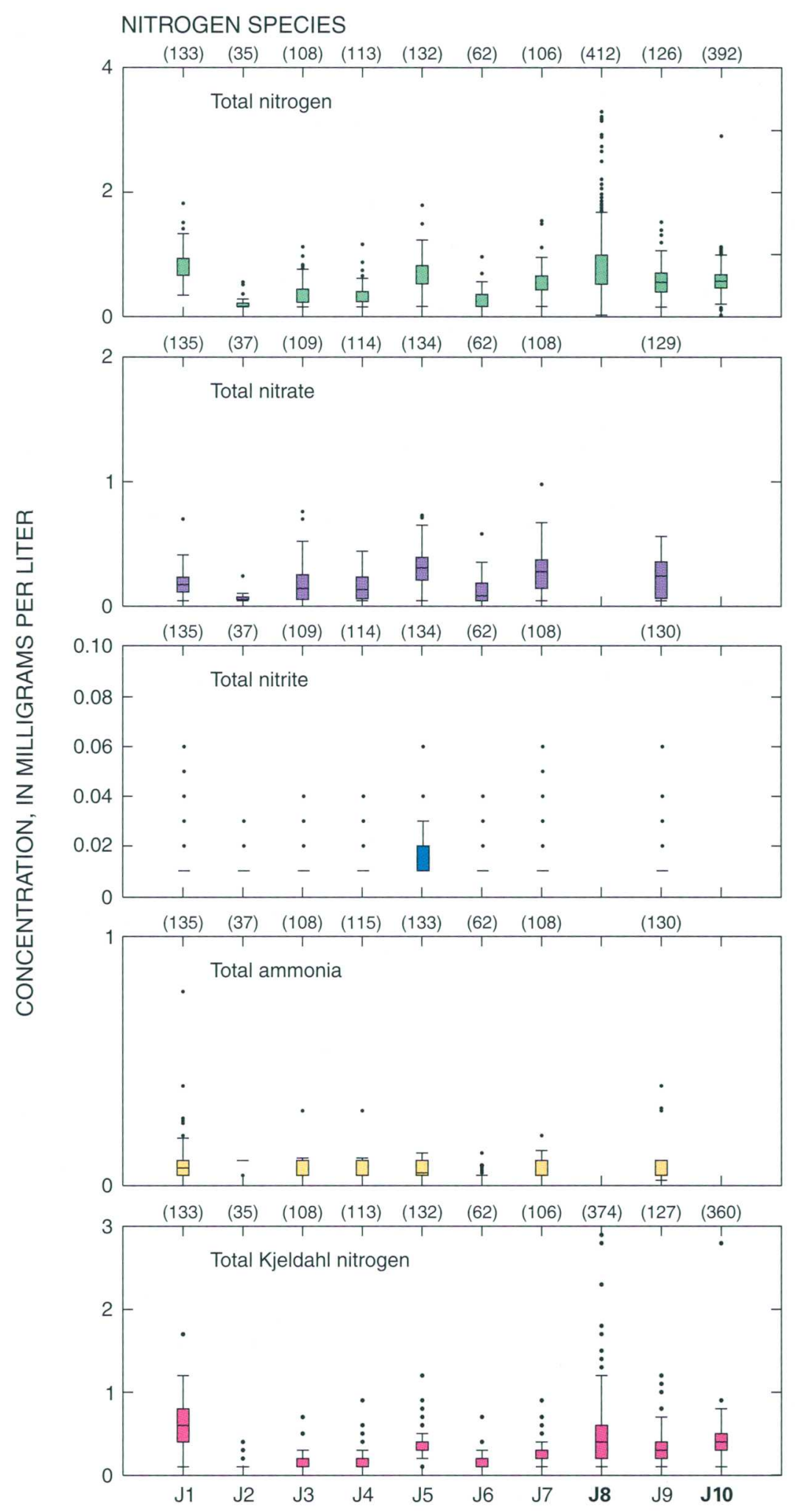

Figure 10. Distribution of concentrations of selected constituents at stations in the James River Basin, Virginia. (River input monitoring stations are printed in bold type.) 


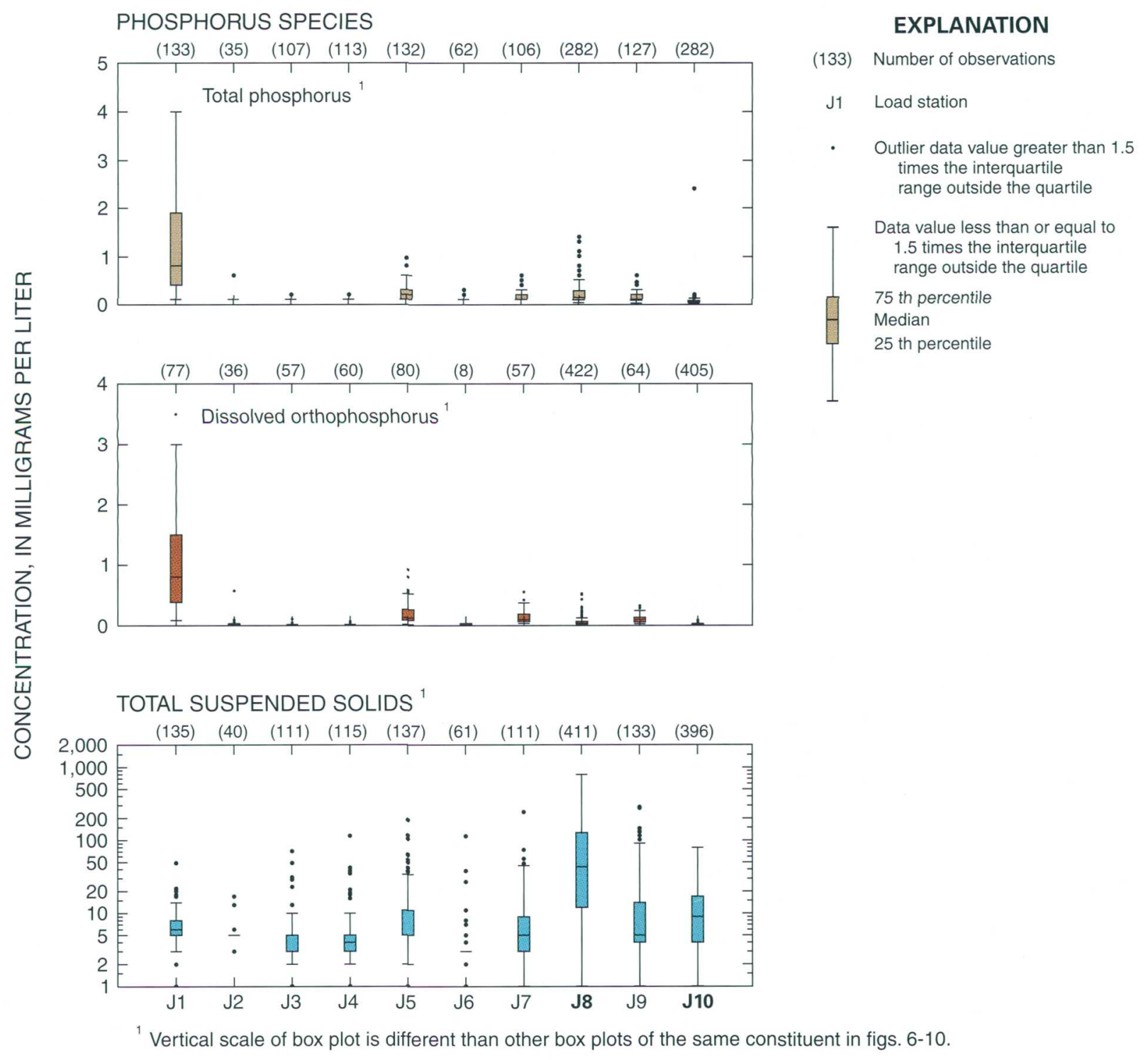

Figure 10.-Continued. 
Table 5. Mean annual load of total nitrogen, total phosphorus, and total suspended solids at each load station in order of increasing basin area in the Chesapeake Bay Basin, Virginia

[mean annual load is reported in tons per year (tons/yr); $\mathrm{mi}^{2}$, square mile; - , indicates no data available]

\begin{tabular}{|c|c|c|c|c|}
\hline \multirow[b]{2}{*}{$\begin{array}{l}\text { Load station } \\
\text { number }\end{array}$} & \multirow[b]{2}{*}{$\begin{array}{l}\text { Basin area } \\
\left(\mathrm{mi}^{2}\right)\end{array}$} & \multicolumn{3}{|c|}{ Mean annual load } \\
\hline & & $\begin{array}{c}\text { Total } \\
\text { nitrogen }\end{array}$ & $\begin{array}{c}\text { Total } \\
\text { phosphorus }\end{array}$ & $\begin{array}{l}\text { Total suspended } \\
\text { solids }\end{array}$ \\
\hline $\begin{array}{l}\mathrm{S} 3 \\
\mathrm{~S} 2 \\
\mathrm{RS} \\
\mathrm{S} 12 \\
\mathrm{J6}\end{array}$ & $\begin{array}{l}14 \\
17 \\
28 \\
45 \\
48\end{array}$ & $\begin{array}{c}69 \\
655 \\
21 \\
209 \\
70 \\
7\end{array}$ & $\sqrt{2}$ & 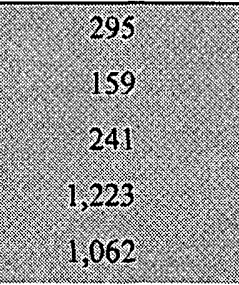 \\
\hline LP1 & 58 & 100 & 9 & 26,965 \\
\hline $\mathrm{S} 1$ & 58 & 115 & - & - \\
\hline S5 & 74 & 193 & 28 & 3,356 \\
\hline $\mathrm{S} 16$ & 87 & 41 & 5 & 2,432 \\
\hline $\mathrm{S} 13$ & 93 & 195 & 23 & 4,150 \\
\hline $\begin{array}{l}\mathrm{S15} \\
\mathrm{J} 2 \\
\mathrm{S7} \\
\mathrm{R} 2 \\
\mathrm{~J}\end{array}$ & $\begin{array}{l}102 \\
105 \\
127 \\
183 \\
188\end{array}$ & 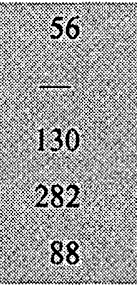 & 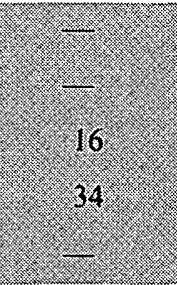 & $(1,404$ \\
\hline S11 & 196 & 181 & 17 & 2,228 \\
\hline S8 & 212 & 440 & 32 & 7,324 \\
\hline $\mathrm{J} 4$ & 330 & 174 & 34 & 15,891 \\
\hline S6 & 372 & 555 & 45 & 19,374 \\
\hline S4 & 377 & 1,357 & - & 10,398 \\
\hline 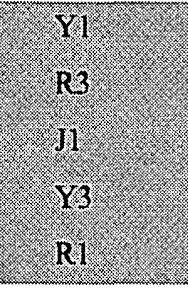 & 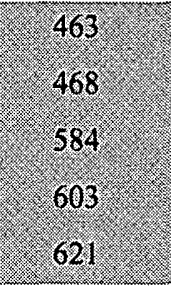 & 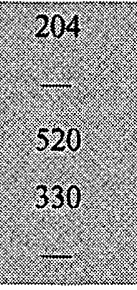 & $\frac{17}{\left(\frac{17}{38}\right.}$ & 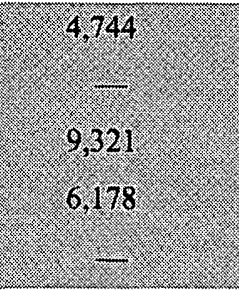 \\
\hline $\mathrm{S} 14$ & 755 & 1,181 & 68 & 25,014 \\
\hline $\mathrm{Y} 2$ & 1,080 & 821 & 95 & 42,973 \\
\hline $\mathrm{J} 10$ & 1,344 & 789 & . 85 & 19,477 \\
\hline S9 & 1,378 & 3,435 & 794 & 119,450 \\
\hline $\mathrm{R} 4$ & 1,598 & 2,657 & 555 & 459,683 \\
\hline $\begin{array}{l}\mathrm{S} 10 \\
\mathrm{J5} \\
\mathrm{J} 7 \\
\mathrm{~J} 8 \\
\mathrm{~J}\end{array}$ & $\begin{array}{l}1,638 \\
3,617 \\
4,520 \\
6,193 \\
6,696\end{array}$ & $\begin{array}{l}2,566 \\
3,207 \\
3,704 \\
6,770 \\
6,020\end{array}$ & 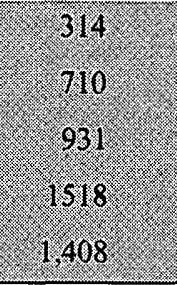 & $\begin{array}{c}57,480 \\
1,2,8,845 \\
177,413 \\
812,894 \\
2,552,279\end{array}$ \\
\hline
\end{tabular}


were estimated for stations $\mathrm{J} 8$ and $\mathrm{J} 9$ in the two largest subbasins, and for R4 in the sixth largest subbasin in the study area.

The three smallest mean annual loads of total nitrogen were found at stations $\mathrm{R} 5, \mathrm{~S} 16$, and $\mathrm{S} 15$, in the $3 \mathrm{rd}, 9$ th, and 11 th smallest subbasins, respectively. The land cover or litho-physiographic characteristics (table 4) of the subbasins containing these stations could account for the small loads. Station R5 represents a subbasin that is unusual in that it has a significant percentage ( 4.4 percent) of its land cover characterized as wetlands, and it is the only subbasin in the study area that lies entirely within the Coastal Plain. The two Shenandoah/Upper Potomac River Basin stations have small percentages of their land area characterized as agriculture.

The three smallest mean annual loads of total phosphorus were calculated for stations among the four smallest subbasins for which data were available (table 5). Data were available to calculate mean annual total phosphorus loads for only 5 stations in the 10 smallest subbasins. All of the stations for which a mean annual load for total phosphorus was not calculated have total phosphorus concentration data available, but many of the values are at or near the detection limit (figs. 6-10). When this occurs, the load estimator model commonly fails to run; however, it is likely that the mean annual total phosphorus load at those stations is similar to the load at station LP1 or S16, which also have many total phosphorus concentration values near the detection limit. The three smallest calculated mean annual loads of total suspended solids were for stations S3, S2, and R5, respectively representing the three smallest subbasins considered in this study.

\section{NUTRIENT AND SUSPENDED SOLIDS YIELDS AND TRENDS}

In order to make meaningful inter-basin comparisons, annual yields were calculated for each constituent by dividing the annual load by the subbasin area. The mean annual yields are summarized in table 6. Flow-adjusted trends (expressed as a percent change during the period of record for a station) and p-values of the log-linear time coefficient for the 35 stations and 8 constituents are shown in table 7 . The median concentration of the first 2 years of record for each constituent at each station also is provided in table 7 to provide a basis from which to evaluate the trend. Yields and trends are described below for each major river basin.

\section{Shenandoah/Upper Potomac River Basin}

Yields were calculated for stations in 16 subbasins in the Shenandoah/Upper Potomac River Basin. About 37 percent of the land area of the Shenandoah/Upper Potomac River Basin is devoted to agriculture, the largest percentage of any major river basin in the study area. In this basin, more than in any other, agriculture refers not only to tilled land, but also to acreage used for pasture. Significant population centers include the cities of Winchester, Harrisonburg, Staunton, and Waynesboro.

In the Shenandoah/Upper Potomac River Basin, the mean annual yield of total nitrogen is related to basin size and land cover. The range of mean annual yields of total nitrogen in streams draining small subbasins is larger than the range of mean annual yields of total nitrogen in streams draining large subbasins. For example, in subbasins smaller than $200 \mathrm{mi}^{2}$, the mean annual yield of total nitrogen ranges from 1.49 (lbs/acre)/yr at Passage Creek near Buckton (S16) to 15.05 (lbs/acre)/yr at Muddy Creek at Mount Clinton (S3), which is the largest value for this study. In contrast, the mean annual yield in streams draining subbasins larger than $200 \mathrm{mi}^{2}$ ranges from 4.66 (lbs/acre)/yr at Middle River near Grottoes (S6) to 11.25 (lbs/acre)/yr at North River near Burketown (S4). A possible explanation for the difference in the ranges between the two sizes of subbasins is the greater likelihood that a small subbasin will contain a large percentage of a single LPR or land cover type than will a large subbasin. For example, the small subbasins containing stations S15 and S16 have small mean annual yields of total nitrogen (less than 2 (lbs/acre)/yr) and each have more than 85 percent of their land area classified as forest. The small subbasins containing stations $\mathrm{S} 2, \mathrm{~S} 3$, and S12 have large mean annual yields of total nitrogen (greater than 10 (lbs/acre)/yr) and each has a combined agricultural and urban land cover percentage greater than 69 percent. In contrast, the two largest subbasins in the Shenandoah/Upper Potomac River Basin, the North Fork Shenandoah River (S14) and South Fork Shenandoah River (S10), have nearly identical mean annual 
Table 6. Mean annual yield and period of record for selected constituents in the Chesapeake Bay Basin, Virginia [yield is reported in pounds per acre per year (lbs/acre)/yr; (period of record); - , indicates no yield was calculated]

\begin{tabular}{|c|c|c|c|c|}
\hline $\begin{array}{l}\text { Load } \\
\text { station } \\
\text { number }\end{array}$ & Total nitrogen & Total ammonia & Total nitrate & $\begin{array}{c}\text { Total } \\
\text { Kjeldahl } \\
\text { nitrogen }\end{array}$ \\
\hline \multicolumn{5}{|c|}{ Shenandoah/Upper Potomac River Basin } \\
\hline$\overline{\mathrm{S} 1}$ & $6.16(1991-96)$ & - & $5.00(1991-96)$ & $2.40(1991-96)$ \\
\hline S2 & $11.85(1985-93)$ & $7.15(1985-87)$ & $6.48 \quad(1985-93)$ & $4.53(1985-93)$ \\
\hline S3 & $15.05(1994-95)$ & - & $12.90(1994-95)$ & $1.92(1994-95)$ \\
\hline S4 & $11.25(1991-96)$ & $.53(1992-96)$ & $8.79(1991-96)$ & $1.87(1991-95)$ \\
\hline S5 & $8.13(1985-96)$ & $.30(1986,88-95)$ & $6.00(1985-96)$ & $2.50(1985-95)$ \\
\hline S6 & $4.66(1985-96)$ & $.18(1985-95)$ & $3.28(1985-95)$ & $1.24(1985-95)$ \\
\hline S7 & $3.21 \quad(1985-95)$ & - & $2.54(1985-95)$ & $.97(1985-95)$ \\
\hline S8 & $6.48(1985-95)$ & - & $5.27(1985-95)$ & $1.73(1986-95)$ \\
\hline S9 & $7.79(1985-96)$ & $.35(1986-95)$ & $5.15(1985-96)$ & $3.25(1986-95)$ \\
\hline $\mathrm{S} 10$ & $4.90(1985-95)$ & $.22(1985-95)$ & $3.73(1985-95)$ & $1.73(1985-95)$ \\
\hline S 11 & $2.88 \quad(1985-95)$ & - & $4.04(1985-95)$ & $.92(1985-95)$ \\
\hline $\mathrm{S} 12$ & $14.46(1993-95)$ & $.24(1993-95)$ & $12.48(1993-95)$ & $1.43(1993-95)$ \\
\hline $\mathrm{S} 13$ & $6.55(1985-96)$ & $.14(1985-96)$ & $5.58(1985-96)$ & $2.99(1985-96)$ \\
\hline S14 & $4.89(1985-95)$ & $.20(1985-95)$ & $4.22(1985-95)$ & $1.27(1985-95)$ \\
\hline $\mathrm{S} 15$ & $1.70(1985-95)$ & - & $1.10(1985-95)$ & $.59(1985-95)$ \\
\hline S16 & $1.49(1985-96)$ & - & $.64(1985-95)$ & $.66(1985-95)$ \\
\hline \multicolumn{5}{|c|}{ Lower Potomac River Basin } \\
\hline$\overline{\mathrm{LP} 1}$ & $5.38(1985-96)$ & $\begin{array}{cl}.36 & (1985-92 \\
& 94-95)\end{array}$ & $3.41 \quad(1985-96)$ & $3.07(1985-96)$ \\
\hline \multicolumn{5}{|c|}{ Rappahannock River Basin } \\
\hline $\mathrm{R} 1$ & - & $.16(1989-91)$ & $1.59(1989-91)$ & $1.28 \quad(1989-91)$ \\
\hline $\mathrm{R} 2$ & $4.81 \quad(1985-96)$ & $.30(1986-94)$ & $2.62(1985-96)$ & $2.98(1985-96)$ \\
\hline R3 & - & $.17(1985-86)$ & - & - \\
\hline $\mathrm{R} 4$ & $5.20(1989-96)$ & - & - & - \\
\hline R5 & $2.31 \quad(1992-96)$ & $.12(1991-96)$ & $1.05(1991-96)$ & $1.17(1991-96)$ \\
\hline \multicolumn{5}{|c|}{ York River Basin } \\
\hline Y1 & $1.38(1985-95)$ & $.07(1985-1995)$ & $.40(1985-95)$ & $.94 \quad(1985-95)$ \\
\hline $\mathrm{Y} 2$ & $2.38(1990-96)$ & - & - & - \\
\hline $\mathrm{Y} 3$ & $1.71 \quad(1990-96)$ & - & - & - \\
\hline \multicolumn{5}{|c|}{ James River Basin } \\
\hline $\mathrm{Jl}$ & $2.78(1985-96)$ & - & $.93(1985-96)$ & $1.80(1985-96)$ \\
\hline $\mathrm{J} 2$ & - & - & - & - \\
\hline J3 & $1.46(1985-95)$ & - & $.70(1985-95)$ & $.88(1985-95)$ \\
\hline $\mathrm{J} 4$ & $1.65(1985-95)$ & - & $.80(1985-95)$ & $.91 \quad(1985-95)$ \\
\hline J5 & $2.77(1985-95)$ & - & $1.50(1985-95)$ & $1.29(1985-95)$ \\
\hline J6 & $4.54(1988-96)$ & - & $1.98(1991-96)$ & .95 (1991-96) \\
\hline $\mathrm{J} 7$ & $2.56(1985-95)$ & $.21(1985-95)$ & $1.53(1985-95)$ & $1.52(1985-95)$ \\
\hline $\mathrm{J} 8$ & $3.42 \quad(1989-96)$ & - & - & - \\
\hline J9 & $2.81 \quad(1985-96)$ & $.28(1985-96)$ & $1.36(1985-96)$ & $2.24(1985-96)$ \\
\hline $\mathrm{J} 10$ & $1.83(1990-96)$ & - & - & $-\cdots$ \\
\hline
\end{tabular}


Table 6.-Continued

\begin{tabular}{|c|c|c|c|c|c|c|c|}
\hline \multicolumn{2}{|c|}{$\begin{array}{c}\text { Total nitrite }+ \text { nitrate } \\
\left(\mathrm{NO}_{2}^{-}+\mathrm{NO}_{3}^{-}\right)\end{array}$} & \multicolumn{2}{|c|}{ Total phosphorus } & \multicolumn{2}{|c|}{ Dissolved phosphorus } & \multicolumn{2}{|c|}{ Total suspended solids } \\
\hline \multicolumn{8}{|c|}{ Shenandoah/Upper Potomac River Basin } \\
\hline 4.62 & $(1991-96)$ & & - & & - & & - \\
\hline & - & 1.92 & $(1985-93)$ & 3.71 & $(1985-87)$ & 28.94 & $(1985-93)$ \\
\hline 13.04 & $(1994-95)$ & & - & & - & 64.36 & $(1994-95)$ \\
\hline 8.71 & $(1991-96)$ & & - & & - & 86.24 & $(1991-95)$ \\
\hline 5.81 & $(1985-96)$ & 1.17 & $(1985-95)$ & & - & 141.30 & $(1986,88,90,92)$ \\
\hline 3.61 & $(1985-96)$ & .38 & $(1985-95)$ & .21 & $(1985-95)$ & 162.71 & $(1986,88-91,93-95)$ \\
\hline 2.27 & $(1985-95)$ & .38 & $(1985-95)$ & & - & 101.05 & $(1986-95)$ \\
\hline 4.85 & $(1985-95)$ & .47 & $(1986-95)$ & & - & 107.79 & $(1986,88-95)$ \\
\hline 5.14 & $(1985-96)$ & 1.80 & $(1985-96)$ & & - & 270.79 & $(1986,88-91,94-95)$ \\
\hline 3.62 & $(1985-95)$ & .60 & $(1985-95)$ & & - & 109.67 & $(1986,88-95)$ \\
\hline 2.05 & $(1985-95)$ & .27 & $(1985-95)$ & & - & 35.51 & $(1989,90,93)$ \\
\hline 12.72 & $(1993-95)$ & - & & & - & 84.53 & $(1993-95)$ \\
\hline 5.26 & $(1985-96)$ & .78 & $(1985-96)$ & & - & 139.23 & $(1986,89-91,93-95)$ \\
\hline & - & .28 & $(1985-95)$ & & - & 103.55 & $(1986,88-92,94-95)$ \\
\hline & - & & - & .07 & $(1986-87)$ & 42.89 & $(1985-95)$ \\
\hline & - & .17 & $(1985-95)$ & - & & 87.66 & $(1986-91,93-95)$ \\
\hline \multicolumn{8}{|c|}{ Lower Potomac River Basin } \\
\hline 3.33 & $(1985-96)$ & .47 & $(1985-96)$ & .30 & $(1986-88,90-91)$ & 1454.20 & $(1987-88,95)$ \\
\hline \multicolumn{8}{|c|}{ Rappahannock River Basin } \\
\hline & - & .37 & $(1989-91)$ & & - & & - \\
\hline 2.59 & $(1985-96)$ & .59 & $(1985-96)$ & & - & 1456.95 & $(1986-88,91-92,94)$ \\
\hline & - & & - & & - & & - \\
\hline & - & 1.08 & $(1989-96)$ & .08 & $(1989-96)$ & 898.94 & $(1989-96)$ \\
\hline & - & & - & & - & 26.44 & $(1991-96)$ \\
\hline \multicolumn{8}{|c|}{ York River Basin } \\
\hline .43 & $(1985-95)$ & .11 & $(1985-95)$ & & - & 32.05 & $(1985-95)$ \\
\hline & - & .27 & $(1990-96)$ & .05 & $(1990-96)$ & 124.40 & $(1990-96)$ \\
\hline & - & .17 & $(1990-96)$ & .04 & $(1990-96)$ & 32.02 . & $(1990-96)$ \\
\hline \multicolumn{8}{|c|}{ James River Basin } \\
\hline & - & 3.15 & $(1985-96)$ & & - & 49.84 & $(1985-96)$ \\
\hline & - & & - & .17 & $(1985-87)$ & & - \\
\hline & - & & - & & - & 68.64 & $(1986-91,93-94)$ \\
\hline & - & .33 & $(1985-95)$ & & - & 150.38 & $(1986-91,93-94)$ \\
\hline & - & .61 & $(1985-95)$ & & - & 106.14 & $(1986-95)$ \\
\hline & - & & - & & - & 68.66 & $(1993-94)$ \\
\hline 1.25 & $(1985-95)$ & .64 & $(1985-95)$ & & - & 122.67 & $(1986-95)$ \\
\hline & - & .77 & $(1989-96)$ & .19 & $(1989-96)$ & 410.18 & $(1989-96)$ \\
\hline 1.03 & $(1985-96)$ & .66 & $(1985-96)$ & & - & 1191.15 & $(1986-96)$ \\
\hline & - & .20 & $(1990-96)$ & .04 & $(1990-96)$ & 45.30 & $(1990-96)$ \\
\hline
\end{tabular}


Table 7. Calculated trends at each load station in the Chesapeake Bay Basin, Virginia [trend is reported as percent change during period of record; median concentration is reported in milligrams per liter ( $\mathrm{mg} / \mathrm{L}$ ); $\mathrm{p}$-value, probability value. Trends significant at the 95 -percent confidence level and above are highlighted and printed in bold type. Trends significant at the 90 -percent confidence level and above are printed in bold type. —, indicates no trend was calculated]

\begin{tabular}{|c|c|c|c|c|c|c|c|c|c|c|c|c|}
\hline \multirow[b]{2}{*}{$\begin{array}{l}\text { Load } \\
\text { station } \\
\text { number }\end{array}$} & \multicolumn{3}{|c|}{ Total nitrogen } & \multicolumn{3}{|c|}{ Total ammonia } & \multicolumn{3}{|c|}{ Total nitrate } & \multicolumn{3}{|c|}{ Total Kjeldahl nitrogen } \\
\hline & $\begin{array}{l}\text { median } \\
\text { concen- } \\
\text { tration }^{1}\end{array}$ & trend & p-value & $\begin{array}{l}\text { median } \\
\text { concen- } \\
\text { tration }^{1}\end{array}$ & trend & p-value & $\begin{array}{l}\text { median } \\
\text { concen- } \\
\text { tration }^{1}\end{array}$ & trend & p-value & $\begin{array}{l}\text { median } \\
\text { concen- } \\
\text { tration }^{1}\end{array}$ & trend & p-value \\
\hline
\end{tabular}

\begin{tabular}{|c|c|c|c|c|c|c|c|c|c|c|c|c|}
\hline \multicolumn{13}{|c|}{ Shenandoah/Upper Potomac River Basin } \\
\hline$\overline{\mathrm{S} 1}$ & 2.415 & -15 & 0.3426 & 0.04 & - & - & 2.120 & -15 & 0.3573 & 0.300 & 34 & 0.0120 \\
\hline S2 & 4.650 & -64 & 0000 & .40 & - & - & 2.200 & -10 & .5674 & 1.450 & -98 & .0000 \\
\hline S3 & 5.970 & -22 & .0736 & .06 & - & - & $5: 015$ & -1 & .9379 & 500 & -74 & 0283 \\
\hline S4 & 3.550 & -7 & .7040 & .04 & 32 & .6772 & 3.055 & -6 & .7693 & .400 & -17 & .4515 \\
\hline S5 & 2.400 & 11 & .1675 & -10 & -61 & 0089 & 1.800 & 8 & .2591 & .300 & 6 & .7207 \\
\hline S6 & 1.500 & 8 & .3480 & .10 & -30 & .2647 & 1.180 & 11 & .1603 & .300 & -11 & .4597 \\
\hline S7 & .810 & 15 & .3158 & .10 & - & - & .600 & 3 & .7332 & .200 & -8 & .6798 \\
\hline S8 & 4.075 & -75 & .0000 & .10 & - & - & 3.095 & -64 & 00000 & 900 & 886 & .0000 \\
\hline S9 & 2.075 & -10 & .1907 & 10 & -69 & .0000 & 1.470 & 19 & 0331 & $500^{\circ}$ & -52 & .0000 \\
\hline $\mathrm{S} 10$ & 1.410 & -7 & .5585 & 10 & -62 & .0004 & 885 & 33 & 0484 & $500^{\circ}$ & -50 & 0000 \\
\hline S11 & .965 & 3 & .8613 & .10 & - & - & 600 & -29 & .0357 & .125 & -37 & .0020 \\
\hline $\mathrm{S} 12$ & 4.525 & -5 & .5864 & .04 & -42 & .2549 & 3.705 & 2 & .8385 & .350 & -37 & .2318 \\
\hline $\mathrm{S} 13$ & 1.726 & 21 & .0473 & .10 & -39 & .3282 & 1.480 & 21 & .1057 & .300 & -9 & .4999 \\
\hline S14 & 1.280 & 51 & .0002 & .10 & -35 & .2962 & .990 & 120 & 0000 & .300 & -18 & .1506 \\
\hline S15 & .705 & 11 & .2391 & .10 & - & - & .530 & 21 & .0867 & .150 & -14 & .3116 \\
\hline $\mathrm{S} 16$ & 260 & -28 & $\sqrt{10203}$ & .10 & - & - & .050 & -35 & .2367 & .100 & -24 & .0495 \\
\hline
\end{tabular}

Lower Potomac River Basin

\begin{tabular}{|c|c|c|c|c|c|c|c|c|c|c|c|c|}
\hline LPI & 1.010 & 54 & .0002 & .10 & -52 & .0638 & 1.600 & \multicolumn{2}{|c|}{ 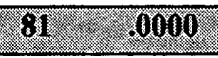 } & .300 & -1 & .9578 \\
\hline \multicolumn{13}{|c|}{ Rappahannock River Basin } \\
\hline $\mathrm{R} 1$ & .660 & - & - & .10 & 17 & .2378 & .360 & -2 & .9384 & .250 & 6 & .7975 \\
\hline $\mathrm{R} 2$ & .750 & 16 & .3198 & .10 & -48 & .2078 & .500 & -1 & .9118 & .200 & 14 & .4027 \\
\hline R3 & .720 & - & - & .10 & - & - & .490 & - & - & .300 & - & - \\
\hline $\mathrm{R} 4$ & 1.085 & -26 & .0000 & - & - & - & - & - & - & - & - & 一 \\
\hline R5 & .660 & 4 & .6888 & .04 & -27 & .2259 & .240 & 23 & .5622 & .400 & 21 & .1874 \\
\hline \multicolumn{13}{|c|}{ York River Basin } \\
\hline $\mathrm{Yl}$ & .365 & 3 & .7991 & 10 & -61 & .0000 & .120 & -6 & .6798 & .200 & 38 & .0289 \\
\hline Y2 & .690 & -4 & .4712 & - & - & - & - & - & - & - & - & - \\
\hline Y3 & .590 & -16 & .0005 & - & - & - & - & - & - & - & - & - \\
\hline \multicolumn{13}{|c|}{ James River Basin } \\
\hline $\mathrm{J} 1$ & .690 & 35 & .0002 & .10 & - & - & .180 & 24 & .0929 & 500 & $\sqrt{47}$ & 0002 \\
\hline $\mathrm{J} 2$ & .180 & - & - & .10 & - & - & .050 & - & 一 & .100 & - & - \\
\hline $\mathrm{J} 3$ & .360 & -18 & .0875 & .10 & - & - & .095 & 6 & .7578 & .100 & -37 & .0056 \\
\hline J4 & .260 & -22 & .0164 & .10 & - & - & 125 & -4 & 0014 & .100 & 15 & .3606 \\
\hline $\mathrm{J} 5$ & .560 & 15 & .1304 & .10 & - & - & 290 & -32 & 0.0129 & 200 & 81 & 0000 \\
\hline $\mathrm{J} 6$ & 280 & -60 & .0298 & .04 & - & - & .120 & -42 & .1143 & .100 & -20 & .4341 \\
\hline $\mathrm{J} 7$ & .565 & -1 & .9973 & 10 & -52 & 10023 & .300 & -47 & .0025 & 250 & 32 & .0389 \\
\hline J8 & .740 & -11 & .0742 & - & - & - & - & - & - & - & - & - \\
\hline J9 & .665 & -20 & .0659 & .10 & -65 & .0000 & 300 & -58 & .0033 & .300 & 9 & .4999 \\
\hline $\mathrm{J} 10$ & .560 & -3 & .6493 & - & - & - & - & - & - & - & - & - \\
\hline
\end{tabular}

${ }^{1}$ Median concentration for the first 2 years of available data. 
Table 7.-Continued

\begin{tabular}{|c|c|c|c|c|c|c|c|c|c|c|c|}
\hline \multicolumn{3}{|c|}{$\begin{array}{l}\text { Total nitrite }+ \text { nitrate } \\
\left(\mathrm{NO}_{2}^{-}+\mathrm{NO}_{3}^{-}\right)\end{array}$} & \multicolumn{3}{|c|}{$\begin{array}{c}\text { Dissolved nitrite + nitrate } \\
\left(\mathrm{NO}_{2}^{-}+\mathrm{NO}_{3}^{-}\right)\end{array}$} & \multicolumn{3}{|c|}{ Total phosphorus } & \multicolumn{3}{|c|}{ Total suspended solids } \\
\hline $\begin{array}{l}\begin{array}{l}\text { median } \\
\text { concen- } \\
\text { tration }\end{array}\end{array}$ & trend & p-value & $\begin{array}{l}\text { median } \\
\text { concen- } \\
\text { tration }{ }^{1}\end{array}$ & trend & p-value & $\begin{array}{l}\text { median } \\
\text { concen- } \\
\text { tration }{ }^{1}\end{array}$ & trend & p-value & $\begin{array}{l}\text { median } \\
\text { concen- } \\
\text { tration }{ }^{1}\end{array}$ & trend & p-value \\
\hline \multicolumn{12}{|c|}{ Shenandoah/Upper Potomac River Basin } \\
\hline 2.130 & -8 & 0.6672 & $\overline{-}$ & - & - & 0.100 & - & - & $\overline{4}$ & -51 & 0.1272 \\
\hline 2.500 & - & - & - & - & - & 1.100 & -99 & .0000 & 6 & 83 & .0001 \\
\hline 5.120 & -8 & .6316 & - & - & - & .100 & - & - & 14 & -40 & .4772 \\
\hline 3.145 & -12 & .5715 & - & - & - & .200 & - & - & 7 & -34 & .2425 \\
\hline 1.810 & 17 & .0469 & - & - & 一 & 300 & -39 & .0005 & 11 & 5 & .8845 \\
\hline 1.200 & 15 & .3642 & - & - & - & 200 & -62 & 0000 & 6. & 255 & 0019 \\
\hline 610 & 28 & .0488 & - & - & - & 100 & -34 & 0047 & 6 & -34 & .1055 \\
\hline 3.150 & -70 & .0000 & - & - & - & 300 & -65 & .0000 & 5 & -15 & .4366 \\
\hline 1.500 & 10 & .2361 & - & - & - & 300 & -40 & .0000 & 8 & -31 & .1192 \\
\hline .905 & 41 & .0472 & - & - & - & .200 & -52 & .0003 & 5 & 53 & 0045 \\
\hline .610 & 63 & .2228 & - & - & - & .100 & -28 & .0597 & 5 & -46 & .3689 \\
\hline 3.740 & -2 & .8609 & - & - & - & .100 & 一 & - & 12 & -49 & .1298 \\
\hline 1.500 & 30 & .0524 & - & - & - & .200 & 8 & .5884 & 5 & -14 & .6052 \\
\hline 1.000 & - & - & - & - & - & .100 & -2 & .8736 & 5 & -37 & .1871 \\
\hline .540 & - & - & - & - & - & .100 & - & - & 5 & -13 & .5963 \\
\hline .060 & - & - & - & - & - & .100 & -13 & .2174 & 5 & -65 & 0060 \\
\hline \multicolumn{12}{|c|}{ Lower Potomac River Basin } \\
\hline 2.650 & 978 & .0001 & - & - & - & .100 & -21 & .2841 & 6 & -53 & 0253 \\
\hline \multicolumn{12}{|c|}{ Rappahannock River Basin } \\
\hline .370 & - & - & - & - & - & .100 & 152 & .0000 & 5 & - & - \\
\hline .510 & 21 & .2787 & - & - & - & .100 & -5 & .8446 & 5 & 30 & .2460 \\
\hline .500 & - & - & - & - & - & .100 & - & - & 5 & - & - \\
\hline - & - & - & .570 & -21 & .0614 & 100 & -40 & .0001 & 30 & 59 & 0000 \\
\hline .250 & - & - & - & - & - & .100 & - & - & 7 & 25 & .4288 \\
\hline \multicolumn{12}{|c|}{ York River Basin } \\
\hline .130 & 0 & .9967 & - & - & - & 100 & -80 & .0000 & 5 & 5 & .8564 \\
\hline - & - & - & .220 & 20 & .0074 & .070 & -2 & .8390 & 24 & -1 & .9484 \\
\hline - & - & - & 140 & -35 & .0000 & .050 & -18 & .0102 & 8 & 2 & .8955 \\
\hline \multicolumn{12}{|c|}{ James River Basin } \\
\hline .200 & - & - & - & - & - & 1.700 & -78 & .0000 & 8 & 9 & .6346 \\
\hline .060 & - & - & - & - & - & .100 & - & - & 5 & - & - \\
\hline .105 & - & - & - & - & - & .100 & - & - & 5 & -68 & 0064 \\
\hline .135 & - & - & - & - & - & .100 & -6 & .4142 & 5 & -45 & .0521 \\
\hline .300 & - & - & - & - & - & .200 & -35 & 0063 & 5 & 83 & .0141 \\
\hline .130 & - & - & - & - & - & .100 & - & - & 3 & -48 & .4401 \\
\hline .310 & -28 & .3840 & - & - & - & .200 & -40 & .0014 & 5 & 33 & .2309 \\
\hline - & - & - & .290 & -12 & .0851 & .170 & -38 & .0000 & 62 & -21 & .0952 \\
\hline 310 & -56 & .0000 & - & - & - & 200 & -65 & .0000 & 5 & -3 & .8888 \\
\hline- & - & - & .160 & -8 & .4713 & .040 & 16 & .0878 & 10 & 9 & .4128 \\
\hline
\end{tabular}


Table 8. Ranges of mean annual yields of major nutrients and total suspended solids in the Shenandoah/Upper Potomac River Basin, Virginia

[yield is reported in pounds per acre per year (lbs/acre)/yr; $\mathrm{mi}^{2}$, square miles; <, less than; $>$, greater than]

\begin{tabular}{|c|c|c|c|c|c|c|c|c|c|}
\hline \multirow{2}{*}{$\begin{array}{l}\text { Basin } \\
\text { area } \\
\left(\mathrm{mi}^{2}\right)\end{array}$} & \multicolumn{3}{|c|}{$\begin{array}{l}\text { Mean annual yield of } \\
\text { total nitrogen }\end{array}$} & \multicolumn{3}{|c|}{$\begin{array}{l}\text { Mean annual yield of } \\
\text { total phosphorus }\end{array}$} & \multicolumn{3}{|c|}{$\begin{array}{l}\text { Mean annual yield of } \\
\text { total suspended solids }\end{array}$} \\
\hline & minimum & maximum & range & minimum & maximum & range & minimum & maximum & range \\
\hline$<200$ & 1.49 & 15.05 & 13.56 & 0.17 & 1.92 & 1.75 & 28.94 & 141.3 & 112.36 \\
\hline$>200$ & 4.89 & 11.25 & 6.36 & .28 & 1.8 & 1.52 & 86.24 & 270.79 & 184.55 \\
\hline
\end{tabular}

yields of total nitrogen, 4.89 and 4.90 (lbs/acre)/yr, respectively, and nearly identical percentages of all land cover types.

The pattern of a smaller range in the mean annual yields at stations in subbasins larger than 200 $\mathrm{mi}^{2}$ observed for total nitrogen also is seen in the mean annual yields of total phosphorus, although the differences between the ranges is not very large (table 8). The range in the mean annual yields for total suspended solids has a different pattern than for either total phosphorus or total nitrogen. The range and the minimum and maximum values defining the range in mean annual yields of total suspended solids are much greater in subbasins larger than $200 \mathrm{mi}^{2}$ than in subbasins smaller than $200 \mathrm{mi}^{2}$. The reason for this observation is not known.

A series of linear regressions was performed for the stations in the Shenandoah/Upper Potomac River Basin to explore apparent relations between nutrient and suspended solids yields, land cover, and geology. Mean annual yield of total nitrogen was plotted and regressed against each major land cover and each LPR present in the region. Similar regression plots were created for the mean annual yield of total phosphorus and total suspended solids. Only the plots of yields of nutrient and suspended solids against agricultural and forest land covers and Valley and Ridge carbonate and Valley and Ridge siliciclastic LPR's showed clear relations.

In general, stations in subbasins having a large percentage of agricultural land cover have larger mean annual yields of nutrients and total suspended solids than stations in subbasins having a small percentage of agricultural land cover (fig. 11). The relation of percent agriculture to yield of total nitrogen had the largest coefficient of determination $\left(R^{2}\right)$, followed by the relation to total phosphorus. Yields of total suspended solids showed the same relation as those for nitrogen and phosphorus, but contained more outliers and, thus, had the lowest $R^{2}$ values. When regressed against percentage of forest land cover, each constituent had a negative slope, indicating that yields of nutrient and suspended solids decrease with increasing percentage of forest land cover. The percentage of agriculture and forest lands are related because those two land covers make up at least 93 percent of every subbasin in the Shenandoah/Upper Potomac River Basin except Abrams Creek (S2); thus, as the percentage of agriculture increases, the percentage of forest decreases.

Regressions of each constituent with percentage of Valley and Ridge carbonate LPR in the Shenandoah/Upper Potomac River Basin were similar in direction and slope to those obtained for percentage of agriculture; however, the plots of total nitrogen and total suspended solids yields against Valley and Ridge carbonate LPR have slightly lower values of $\mathrm{R}^{2}$

(fig. 12). Regressions of each constituent with percentage of Valley and Ridge siliciclastic LPR indicated relations that were equal and opposite in slope to those performed for the constituents against Valley and Ridge carbonate LPR. As was seen in the agricultural and forest land covers, the percentages of Valley and Ridge carbonate LPR and Valley and Ridge siliciclastic LPR are complementary for most subbasins in the Shenandoah/Upper Potomac River Basin, which means that a decrease in the percentage of one results in an approximately equal increase in the percentage of the other.

A regression of the percentage of agricultural land cover with the percentage of Valley and Ridge carbonate LPR indicates a positive correlation between the two (fig. 13). Because carbonate rocks generally are less resistant to weathering than siliciclastic rocks, they are found primarily in the valleys of 


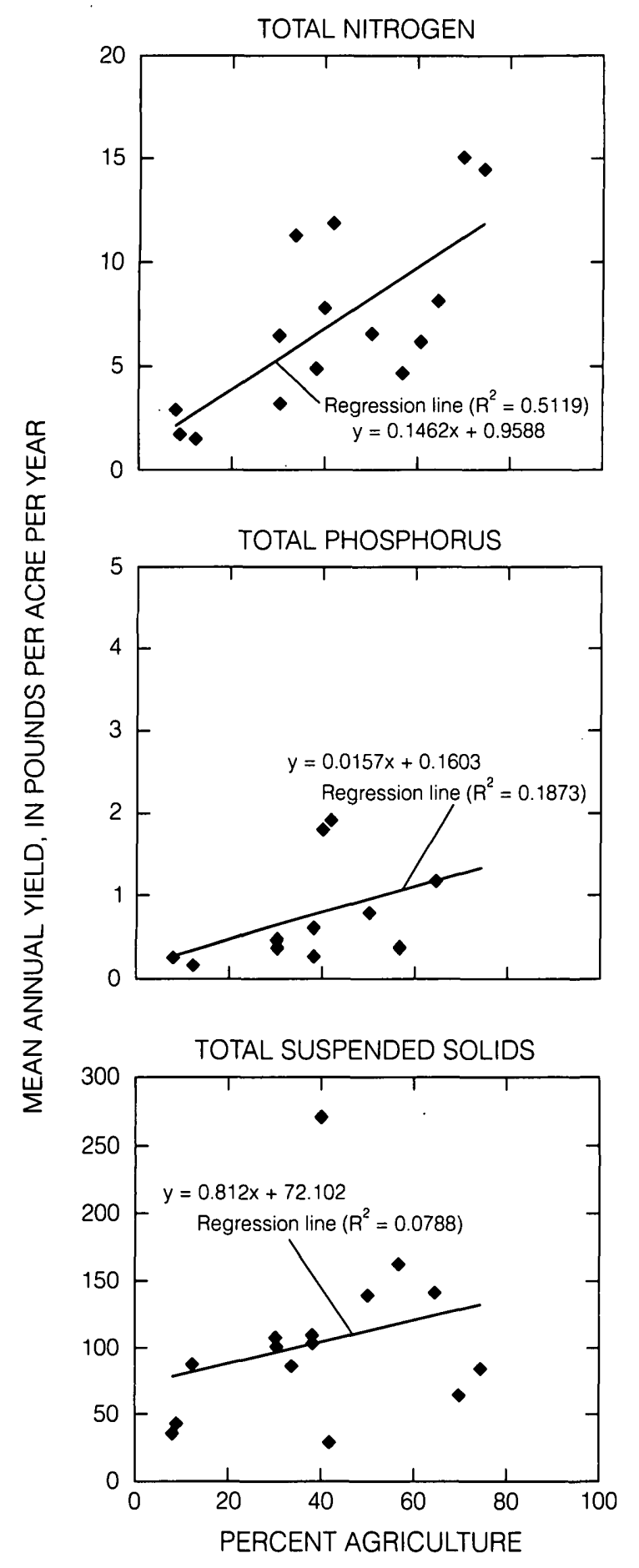

Figure 11: Relation between mean annual yield and percent agriculture land cover in the Shenandoah/Upper Potomac River Basin for: total nitrogen, total phosphorus, and total suspended solids. (The slope of the regression line is expressed as $y=m x+b$ where $y$ is the mean annual yield, $m$ is the slope, $x$ is the percentage of agriculture, and $b$ is the $y$ intercept of the regression line.)

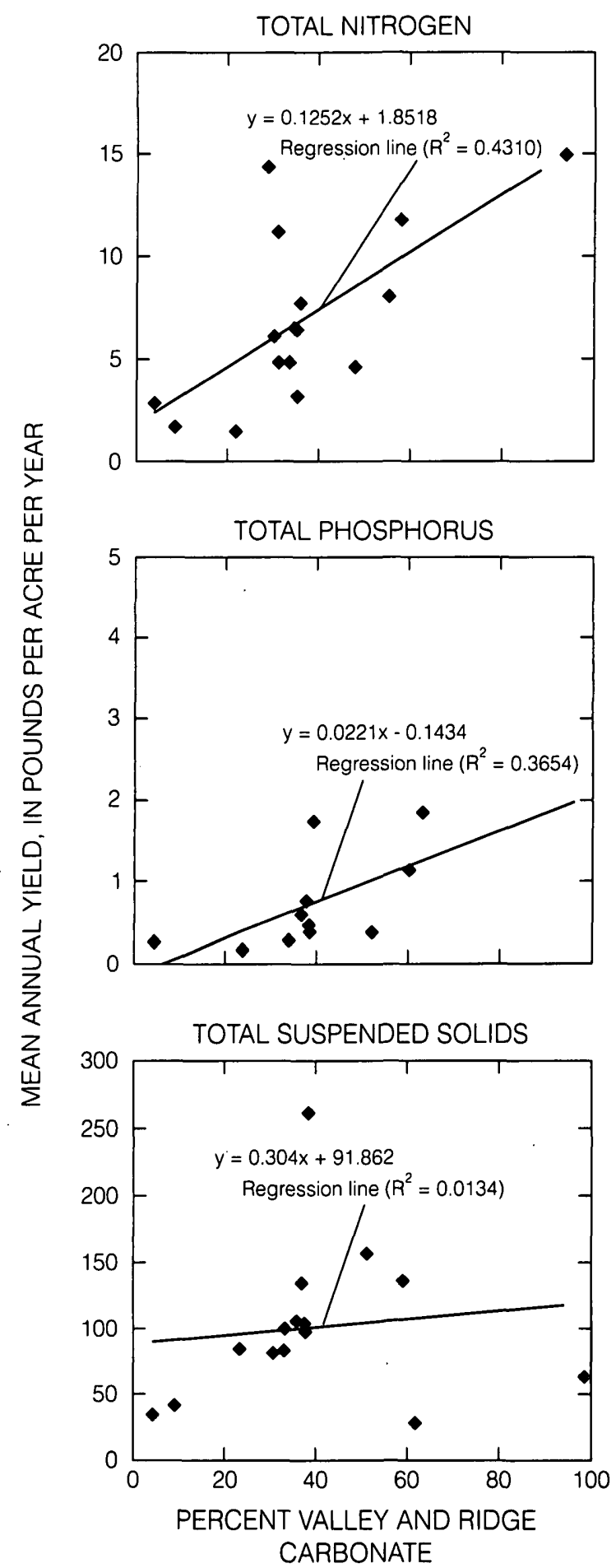

Figure 12. Relation between mean annual yield and percentage of Valley and Ridge carbonate litho-physiographic region in the Shenandoah/ Upper Potomac River Basin for: total nitrogen, total phosphorus, and total suspended solids. (The slope of the regression line is expressed as $y=m x+b$ where $y$ is the mean annual yield $m$ is the slope, $x$ is the percentage of Valley and Ridge carbonate, and $b$ is the $y$ intercept of the regression line.) 


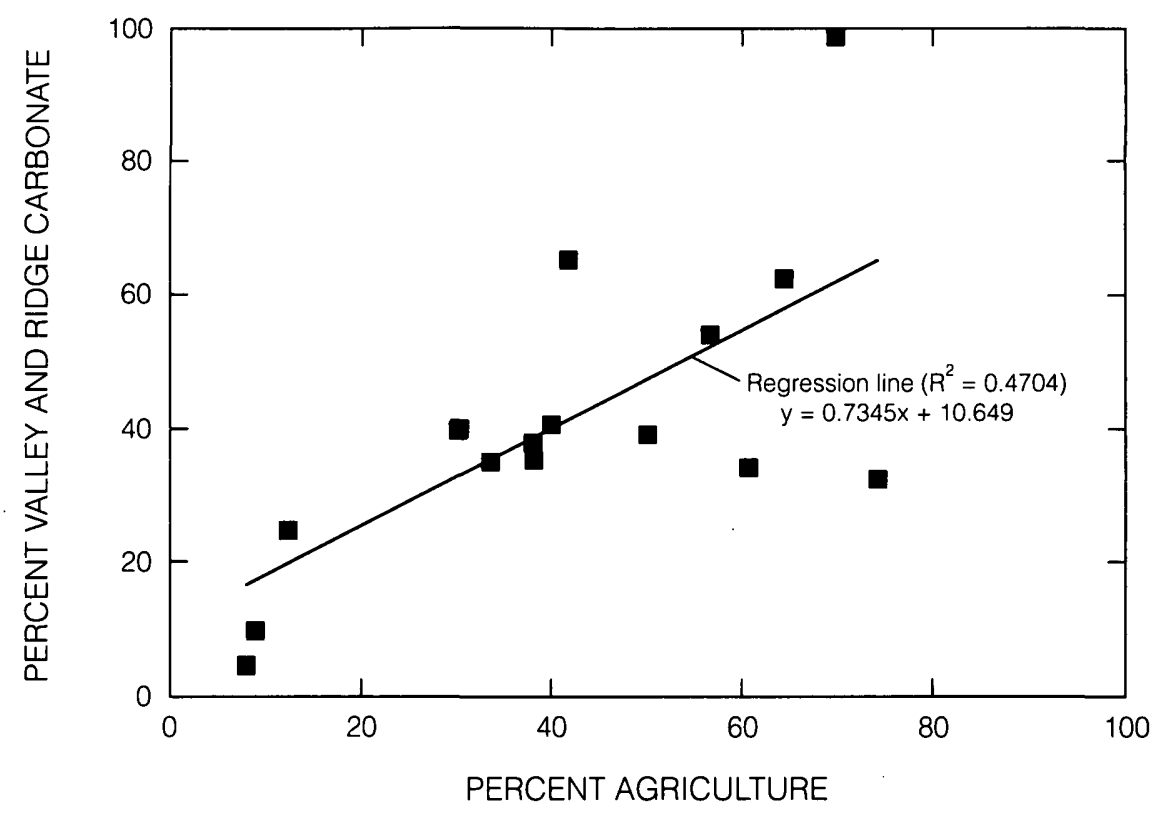

Figure 13. Relation between percent Valley and Ridge carbonate litho-physiographic region and percent agricultural land cover in the Shenandoah/Upper Potomac River Basin. (The slope of the regression line is expressed as $y=m x+b$ where $y$ is the percentage of Valley and Ridge carbonate, $m$ is the slope, $x$ is the percentage of agriculture, and $b$ is the $y$ intercept of the regression line.)

Virginia's mountains. Weathering of these rocks produces soil rich in calcium and magnesium, which is excellent for crop growth. The combination of fertile soil and relatively level valley floors makes the carbonate areas of the Shenandoah/Upper Potomac Basin highly desirable for agriculture.

Of the 16 subbasins in the Shenandoah/Upper Potomac River Basin, only 5 had a statistically significant trend in total nitrogen (table 7). Significant, declining trends in total nitrogen were observed at Abrams Creek (S2), South River (S8), and Passage Creek (S16), but no spatial connection exists between those stations. Significant, increasing trends in total nitrogen were found at Smith Creek (S13) and North Fork Shenandoah River (S14) both of which are in the North Fork Shenandoah River Basin. No other spatial connections seem to exist between stations having significant trends.

Significant, downward trends in total phosphorus were detected at all six load stations in the South Fork Shenandoah River Basin for which total phosphorus data were available. The downward trends ranged from 34 to 65 percent, and all were statistically significant above the 95-percent confidence level. A statistically significant trend in total phosphorus was detected at only one of the three stations in the North Fork Shenandoah River Basin for which data were available. A downward trend of 28 percent (significant at the 90-percent confidence level) was detected at station S11, the most upstream and least developed station in North Fork Shenandoah River Basin.

Significant trends in total suspended solids were detected at stations in four subbasins in the Shenandoah/Upper Potomac River Basin. The stations are widely separated and have no apparent geologic, hydrologic, or land cover similarities. In all cases, the trends in total suspended solids were downward, and at three of the four stations trends in total phosphorus were also downward.

\section{Lower Potomac River Basin}

The Lower Potomac River Basin contains a single load station, Difficult Run (LP1) (fig. 1). The Difficult Run watershed is a $58 \mathrm{mi}^{2}$, moderately urbanized basin ( 25 percent) that drains parts of the cities of Manassas, Fairfax, and Vienna. About 52 percent of the basin is classified as forest and only about 20 percent is used for agricultural purposes (table 4). 
The basin contains one of the larger percentages of wetlands ( 1.5 percent) in the study area. Ninety-eight percent of the basin is classified as Piedmont crystalline LPR.

The mean annual yields of total nitrogen and total phosphorus at the Difficult Run station are much larger than those for stations in other subbasins having a similar percentage of agricultural land cover (tables 4 and 6). This may be due to the large percentage of urban land cover in the Difficult Run watershed. Abrams Creek (S2), another highly urbanized subbasin, also has high mean annual yields of total nitrogen and total phosphorus. The difference in the magnitude of the yield of total nitrogen between these two urban subbasins may be due to a larger percentage of agriculture in the Abrams Creek watershed or the different LPR's in which the two subbasins are located. Although the mean annual yield of total suspended solids in the Difficult Run subbasin is the second largest in the study area, the value may be significantly in error. Yields from only three years of record (1987, 1994, and 1995) were used in the calculation, and the estimated error in the load associated with these years was between 65 and 70 percent. Loads for the intervening years were eliminated because they had estimated errors greater than 80 percent.

Two statistically significant trends were detected at the Difficult Run load station. An increase in the concentration of total nitrogen (54 percent) for the period of record may be due to the increasing use and (or) overapplication of lawn fertilizers by the expanding suburbs and businesses in Northern Virginia. A significant 53-percent decrease in the concentration of total suspended solids was detected in the basin during the same period. The observed decline in total suspended solids may be related to land use changes or it may be due to errors in the estimation of the loads resulting from a lack of data from high streamflow conditions, which may result in errors in the estimate of the flow adjusted trend coefficeint, $\beta_{3}$.

\section{Rappahannock River Basin}

Five subbasins are within the Rappahannock River Basin, each having similar land cover. At least 60 percent of each subbasin is forested, approximately 30 percent is agriculture, and less than 1.5 percent of each subbasin is urbanized. The four upland subbasins, represented by stations R1, R2, R3, and R4 lie within three LPR's - Blue Ridge, Piedmont crystal- line, and Mesozoic basin fill. Piscataway Creek (R5) lies entirely in the Coastal Plain and is much smaller than the other four subbasins.

Mean annual yields of total nitrogen and total suspended solids are greater at the two upland subbasin stations than at the Piscataway Creek station (R5), even though the percentages of agricultural and forest land cover in each subbasin are similar. The relatively large percentage of wetlands ( 4.4 percent) and lack of any significant urbanization in the Piscataway Creek subbasin may contribute to the low yields calculated at station R5. Mean annual yield of total phosphorus increases from the upland subbasins down to the RIM station on the Rappahannock River near Fredericksburg (R4). Discharge from wastewater treatment plants near the cities of Remington, Culpepper, and Orange may contribute to the higher phosphorus yields observed at this station. Not enough data points are available to generate regressions of mean annual yield with land use or LPR for this major river basin.

Significant trends in total nitrogen and total suspended solids were detected at the RIM station near Fredericksburg (R4). In addition, a significant trend in total phosphorus was detected at the Fredericksburg station and at the Rappahannock River at Remington (R1). The 152-percent increase in total phosphorus concentration calculated at the Rappahannock River at Remington represents a change from a small initial concentration over a short time period (1990-94), and may not be representative of the long-term trends at that station. Long-term, basin-wide conditions as measured at the RIM station near Fredericksburg show a 26-percent decline in total nitrogen concentration, a 40-percent decline in total phosphorus concentration, and a 59-percent decline in total suspended solids concentration, and thus indicate greatly improving water-quality conditions in the Rappahannock watershed. Bell and others (1996) also found significant downward trends of these constituents at this station and suggested that implementation of agricultural best-management practices (BMP's) may be responsible for these changes.

\section{York River Basin}

Three stations in subbasins within the York River Basin met the criteria for load calculations. The North Anna River, represented by station Y1, drains to the Pamunkey River, represented by Y2. The Mattaponi River, represented by station Y3, joins the 
Pamunkey River outside of the study area to form the York River. The three subbasins have similar types and distribution of land cover. Agriculture accounts for 20 to 24 percent of the area of each subbasin.

Sixty-seven to 70 percent of each subbasin is covered by forest. Both the Pamunkey and Mattaponi River subbasins contain a relatively large percentage of wetlands, 5.7 and 3 percent, respectively. More than 90 percent of both the North Anna and Pamunkey River subbasins are classified as Piedmont crystalline LPR, whereas only 39 percent of the Mattaponi River subbasin lies in the Piedmont crystalline LPR. The remaining 61 percent of the Mattaponi River subbasin is in the Coastal Plain LPR.

Station Y2 on the Pamunkey River has the largest mean annual yields of total nitrogen, total phosphorus, and total suspended solids of the three stations in the York River Basin (table 6). The difference in the mean annual yields of nutrients and suspended solids between station Y2 and station Y1 on the North Anna River probably is due to the presence of Lake Anna, an artificial lake located about 25-river mi upstream of station Y1. The slow-moving water behind the dam allows particulate matter to settle out of the water column. In the Pamunkey River, suspended particulate matter usually carries 50 to 75 percent of the total phosphorus load during most streamflow conditions and 25 to 50 percent of the total nitrogen load during high streamflow conditions. Thus, the settling of suspended material behind the Lake Anna dam would be expected to reduce the estimated yield at stations on the North Anna River below the lake.

Yields of total nitrogen, total phosphorus, and total suspended solids at the Mattaponi River station (Y3) are lower than those calculated for the Pamunkey River station (Y2). This may be due to the larger percentage of wetlands and Coastal Plain LPR in the Mattaponi River subbasin compared to the Pamunkey River subbasin. In general, the Coastal Plain LPR has less variable relief than the Piedmont, which results in lower stream gradients and channel velocities. Lower channel velocities would result in a smaller suspended load being carried by Coastal Plain streams compared to Piedmont streams. As was seen in the North Anna River, a small suspended load can account for small yields of total nitrogen, total phosphorus, and total suspended solids. In addition, a lower gradient and a larger percentage of wetlands in the Mattaponi River subbasin suggest that the water has a longer residence time in the subbasin (compared to the Pamunkey), which would allow more time for nutrients to be utilized through natural processes.

A downward trend in total nitrogen of 16 percent was detected at the Mattaponi River near Beulahville. No statistically significant trends in total nitrogen were found at any other station. Declines in the concentration of total phosphorus were detected at the stations on the North Anna ( -80 percent) and Mattaponi ( -18 percent) Rivers, although the decline at the North Anna station is somewhat deceiving because the initial concentration was low, and a small decrease in the concentration can result in a large percentage decrease in the trend. The observed trends in the Mattaponi River Basin may be attributed to upgrades at the Bowling Green sewage treatment facility (the only significant point source in the basin), the implementation of BMP's in the basin, or a combination of the two.

\section{James River Basin}

The subbasins in the James River Basin account for nearly half of the study area. Most of the upper James River Basin is within the Valley and Ridge siliciclastic LPR whereas the lower basin is primarily within the Piedmont crystalline LPR. Eighty percent of the basin is forested, and although it contains the smallest percentage of agricultural land of any major basin in the study area (17 percent), it has more total area devoted to agriculture than any other major river basin $\left(1,346 \mathrm{mi}^{2}\right)$. Loads could be calculated at only five stations on tributaries to the James River, and no information is available on total nitrogen, total phosphorus, or total suspended solids at one of those stations. The remaining four load stations are on the lower reaches of the mainstem of the James River. These stations are good integrators of upstream conditions. The lack of nutrient and suspended solids data for major tributaries upstream from the James River at Bent Creek (J5) prevents a more detailed examination of nutrient sources and the evolution of the water chemistry in the basin.

The mean annual yields of total nitrogen at stations on the mainstem of the James River change little from the largest headwater subbasin (represented by J1) down to the station at Scottsville (J7), declining from 2.78 to 2.56 (lbs/acre)/yr. Although, water enters the James River from subbasins represented by stations having total nitrogen yields much higher (J6) and 
much lower (J4), no significant effect is observed in the yields measured on the mainstem. The increase in the yield of total nitrogen between Scottsville (J7) and Cartersville $(\mathrm{J} 8)$ may be due to the slight increase in the percentage of agricultural land cover and the slight decrease in the percentage of forested land cover between the two stations (table 4). Because the subbasins represented by these two stations are very large, the small percent changes in land cover actually represent a relatively large area and a potentially significant source of nutrients. The decrease in the mean annual yield of total nitrogen at Richmond (J9) compared to Cartersville (J8) is attributed to error in the estimated loads due to differences in the representativeness of the respective data sets as previously discussed in the section "Estimation of Loads." The estimate of the mean annual yield at Cartersville probably is the more accurate of the two, and therefore should be used to represent the James River Basin as a whole.

In a comparison of subbasins in the study area having similar percentages of agricultural land cover, yields of total phosphorus and total suspended solids calculated at stations in the James River Basin generally are higher than those calculated at stations in the rest of the study area. A reason for this observation is not known. An exception to this observation occurs at the load station on the Appomattox River (J10). The low mean annual yields of total phosphorus and total suspended solids calculated at the Appomattox station probably are the result of settling behind the Lake Chesdin dam, located about $3 \mathrm{mi}$ upstream of the station.

Mean annual yields of total phosphorus and total suspended solids from two headwater subbasins of the James River ( $\mathrm{J} 1$ and $\mathrm{J} 4$ ) differ substantially from those calculated at the James River at Bent Creek (J5), the first station downstream that integrates both subbasins. Additional data from stations in other headwater subbasins would provide more insight into the sources and movement of phosphorus in the upper James River Basin. The mean annual yield of total phosphorus remains relatively constant from Bent Creek down to the Richmond station (J9), but the yield of total suspended solids increases by fourfold between Bent Creek and Cartersville (J8) and again by nearly threefold between Cartersville and Richmond. The cause of the large increase in the yield of total suspended solids between Bent Creek and Cartersville is largely unknown, but may be related to a change in bedrock geology and soil as the James River crosses from the Blue Ridge LPR into the Piedmont crystalline LPR, or it may be due to errors in the load estimates at Bent Creek resulting from a lack of samples collected during high streamflow conditions. The increase in the yield of total suspended solids between Cartersville and Richmond is almost certainly due to errors in the load estimates at Richmond as was discussed previously, in the section "Estimation of Loads." The yields calculated at the Cartersville station probably are the most accurate, and therefore best represent conditions in the non-tidal James River Basin.

Regressions between yields and various basin characteristics, similar to those performed for the Shenandoah/Upper Potomac River Basin (figs. 11 and 12), were performed for the James River Basin. Because of the uniformity in land cover patterns across the basin, the results of regressions of yield with land cover were inconclusive. Data from more diverse subbasins would have allowed a more thorough investigation of yield/land cover relations. Regressions of yield with LPR were only marginally informative. The low percentage of Valley and Ridge carbonate LPR in the James River Basin and the lack of subbasins having large percentages of Piedmont crystalline rocks prevented plots of these constituents from being particularly useful because all the-data was clustered at one end of the LPR axis. Regressions of yields of nutrient and suspended solids with Valley and Ridge siliciclastic LPR showed poor fits and were heavily influenced by one or two outliers. Removal of the outliers produced more satisfactory results, but reduced the number of data points to an unacceptably low number.

An upward trend in total nitrogen was observed at the Jackson River station. This trend is apparent in plots of the yields of total nitrogen (fig. 14A) and total Kjeldahl nitrogen (fig. 14B) even though the yields are not flow adjusted. The trends may be caused by new, higher capacity wastewater treatment facilities brought on-line after 1985 that may be redirecting waste that was previously discharged to the ground-water system by septic tanks. A downward trend in total nitrogen at the 95-percent confidence level is observed at the Maury River (J4) and Piney River (J6) stations. Additionally, downward trends at the 90-percent confidence level were observed in the James River at both the Cartersville (J8) and Richmond (J9) stations. No cause for these trends could not be determined. 

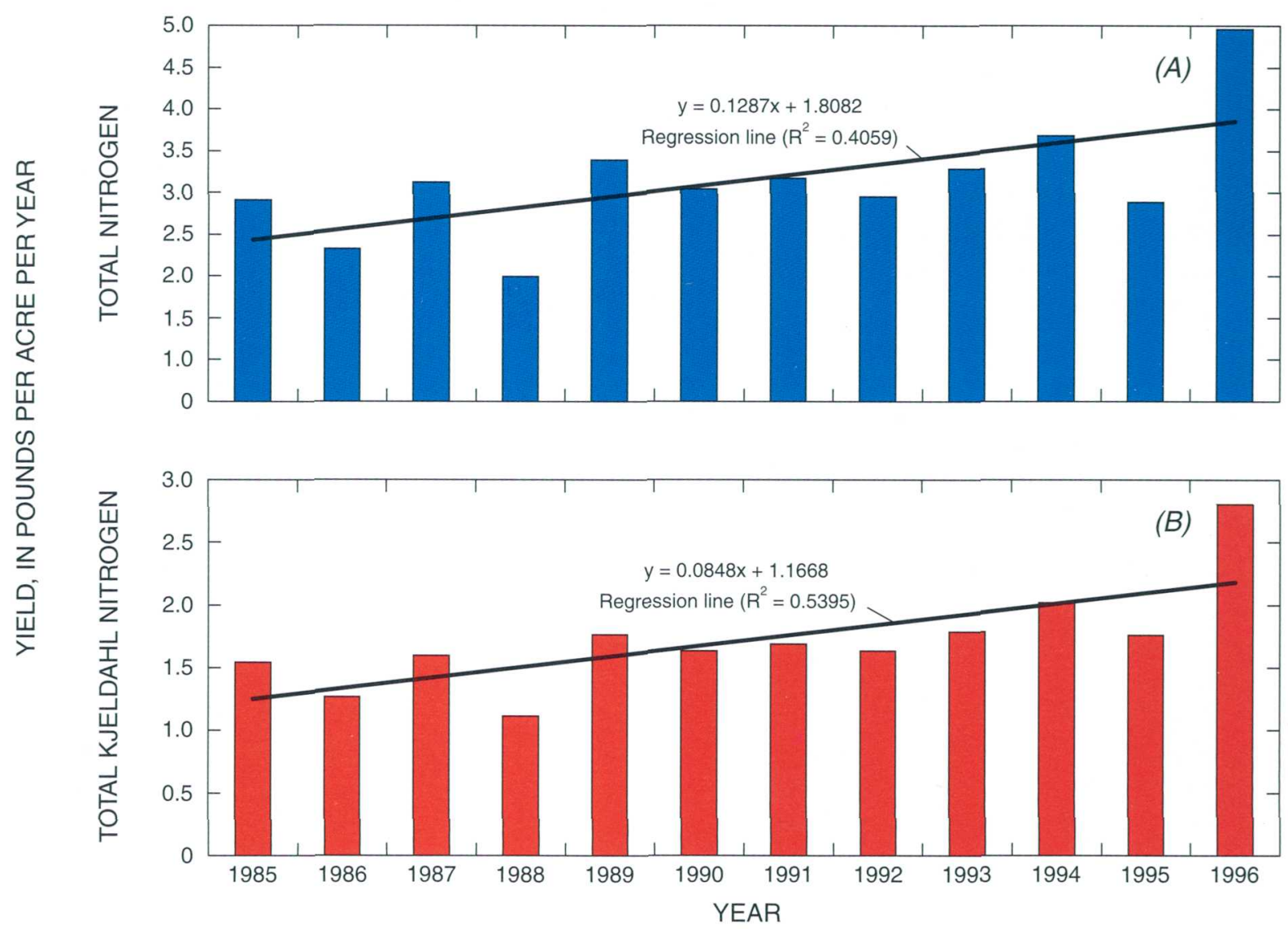

Figure 14. Annual yield of total nitrogen $(A)$, and annual yield of total Kjeldahl nitrogen $(B)$ in the Jackson River Basin since 1985. (The slope of the regression line is expressed as $y=m x+b$ where $y$ is the mean yield, $m$ is the slope, $x$ is the percentage of agriculture, and $b$ is the $y$ intercept of the regression line.)

Flow-adjusted trends in the concentration of total phosphorus showed significant decreases at the 90-percent confidence level at five of the seven stations in the James River Basin for which sufficient data were available; no significant trend was detected at the Maury River station (J4) and an upward trend was detected at the Appomattox station (J10). The most likely cause of these declines is basin-wide improvements in wastewater treatment facilities and the 1988 phosphate detergent ban.

Only two trends in total suspended solids at the 95-percent confidence level were detected.

Flow-adjusted trends in concentration at the Calfpasture River station (J3) decreased by 68 percent and those at the James River at Bent Creek (J5) increased by 83 percent. At the 90 -percent confidence level, additional decreases were detected at the Maury River station (J4) (which contains the Calfpasture River) and at the James River at Cartersville (J8).

\section{CONCLUSIONS}

The five major river basins analyzed for this study differ greatly in land cover and litho-physiographic patterns. In general, the mean annual yield of nutrients and suspended solids tends to increase with percentage of agricultural and urban area. The 
presence of wetlands and dams appear to reduce the yields of nutrient and suspended solids in agricultural and urbanized basins.

In the Shenandoah/Upper Potomac River Basin, nutrient and yield of suspended solids generally were highest in basins having the largest percentage of agricultural land cover. Small basins tend to have little variation in their land cover and litho-physiography. This uniformity is the main reason that many of the highest and lowest yields are found in basins smaller than $200 \mathrm{mi}^{2}$. A basin that is almost 100 percent forested would be expected to yield very little nutrients or suspended solids, whereas a basin having 50 percent or more agricultural and urban area would be expected to have large nutrient and suspended solids yields.

The James River Basin has a small percentage of agriculture, but total phosphorus yields are similar to those found in highly agricultural basins like the Shenandoah/Upper Potomac. Additional information on phosphorus loads from tributaries to the mainstem James River is needed to better understand the sources and mobility of this nutrient in the James River Basin. Total nitrogen yields in the James River Basin are comparable to those found in other basins having similar percentages of agriculture.

In general, flow-adjusted trends of nutrient and suspended solids are decreasing across the study area. Of the 182 trends that were calculated, 72 were statistically significant at the 95-percent confidence level, and of those, 53 were downward and 19 were upward. 'Trends were most consistently observed for total phosphorus, total suspended solids, dissolved ammonia, and total Kjeldahl nitrogen. The overall decline in the concentration of total phosphorus and total suspended solids suggests that stormwater management and erosion controls are having a beneficial effect on the reduction of those constituents. The downward trends observed for ammonia and Kjeldahl nitrogen are not consistently coupled with downward trends in total nitrogen. This suggests that, at some stations, the species of nitrogen is changing, but the total amount is remaining essentially the same.

Significant errors in the estimated loads of total suspended solids were observed at stations in the James River. The errors point to a need for additional sampling during high streamflows to properly characterize this constituent using the load estimator model. Smaller errors in the estimated loads of total nitrogen and total phosphorus also were attributed to the paucity of high-flow samples. Errors in dissolved constit- uents are smaller because (1) concentrations of these nutrients are much smaller than for suspended solids and (2) the range of concentrations of nitrogen and phosphorus is much smaller than the range of concentrations of total suspended solids. This problem is not limited to the James River Basin and may occur at any site that is not adequately sampled during high-flow conditions. A sampling program begun in 1996 on the North Fork Shenandoah and South Fork Shenandoah Rivers will help to address the need for high-flow event concentration data at stations other than the River Input Monitoring stations.

\section{REFERENCES CITED}

Bell, C.F., Belval, D.L., and Campbell, J.P., 1996, Trends in nutrients and suspended solids at the Fall Line of five tributaries to the Chesapeake Bay in Virginia, July 1988 through June 1995: U.S. Geological Survey Water-Resources Investigations Report 96-4191, $37 \mathrm{p}$.

Belval, D.L., and Campbell, J.P., 1996, Water-quality data and estimated loads of selected constituents in five tributaries to the Chesapeake Bay at the Fall Line, Virginia, July 1993 through June 1995: U.S. Geological Survey Open-File Report 96-220, $79 \mathrm{p}$.

Belval, D.L., Campbell, J.P., Phillips, S.W., and Bell, C.F., 1995, Water-quality characteristics of five tributaries to the Chesapeake Bay at the Fall Line, Virginia, July 1988 through June 1993: U.S. Geological Survey Water-Resources Investigations Report 95-4258, $71 \mathrm{p}$.

Belval, D.L., Woodside, M.D., and Campbell, J.P., 1994, Relation of stream quality to streamflow, and estimated loads of selected water-quality constituents in the James and Rappahannock Rivers near the Fall Line of Virginia, July 1988 through 1990: U.S. Geological Survey Water-Resources Investigations Report 94-4042, 85 p.

Bradu, Dan, and Mundlak, Yair, 1970, Estimation in lognormal linear models: Journal of the American Statistical Association, v. 65, no. 329, p. 198-211.

Cohn, T.A., Caulder, D.L., Gilroy, E.J., Zynjuk, L.D., and Summers, R.M., 1992, The validity of a simple statistical model for estimating fluvial constituent loads: An empirical study involving nutrient loads entering Chesapeake Bay: Water Resources Research, v. 28, p. 2,353-2,363.

Cohn, T.A., DeLong, L.L., Gilroy, E.J., Hirsch, R.M., and Wells, D.K., 1989, Estimating constituent loads: Water Resources Research, v. 25, no. 5, p. 937-942. 
Langland; M.J., Lietman, P.L., and Hoffman, Scott, 1995, Synthesis of nutrient and sediment data for watersheds within the Chesapeake Bay drainage basin: U.S. Geological Survey Water-Resources Investigations Report 95-4233, $121 \mathrm{p}$.

Langland, M.J., Edwards, R.E., and Darrell, L.C., 1998, Status yields and trends of nutrients and sediment and methods of analysis for the nontidal data collection programs, Chesapeake Bay Basin: U.S. Geological Survey Open File Report 98-17, 59 p.

Rantz, S.E. and others, 1982, Measurement and computation of streamflow, v. 1 and 2: U.S. Geological Survey Water-Supply Paper 2175, 2 v., 631 p.

U.S. Environmental Protection Agency, 1988, Chesapeake Bay Agreement, in Comprehensive research plan, an agreement commitment report from the Chesapeake Executive Council [variously paged].

1995, The State of the Chesapeake Bay, 1995: Washington, D.C., U.S. Government Printing Office, $45 \mathrm{p}$.

1996, EPA region III land cover data set, version 2: Geographic information system grid coverage.

Virginia Water Control Board, 1988, Virginia Water Quality Assessment-1988, v. 2 of 2: Virginia Water Control Board Information Bulletin 574 [variously paged].

Virginia Department of Conservation and Recreation Division of Soil and Water Conservation, 1995, Virginia's hydrologic unit data layers: Geographic information system polygon coverage. 